\title{
The characteristics of granites in the Gaofeng and Baocheng areas, Hainan Province, China: Response to subduction of the Tethyan South China Sea
}

\author{
Yuan Xiaobo $^{1 *}$, Fang Nianqiao ${ }^{2}$, Zhang Zhenguo $^{4}$ and Dong Hailong ${ }^{3}$ \\ ${ }^{1}$ Hebei Normal University of Science and Technology, Institute of Marine Science, Qinhuangdao, 066004 China; ( ${ }^{*}$ corresponding author: yuanxiaobo2011@163.com) \\ ${ }^{2}$ China University of Geosciences (Beiing), School of Ocean Sciences, Beijing, 100083 China \\ ${ }^{3}$ Nonferrous geological prospecting bureau of Inner Mongolia, Hohhot, 016043 China \\ ${ }^{4}$ Liaoning Technical University, Mining Institute, Fuxin, 123000 China
}

doi: $10.4154 / g c .2019 .19$

Article history:

Manuscript received April 23, 2019

Revised manuscript accepted July 02, 2019

Available online December 20, 2019

\begin{abstract}
During the early Mesozoic Era there was intense magmatic activity near Hainan Island, South China. As a result, the granites of Hainan Island provide information on, and are suitable material to potentially improve understanding of the Cretaceous tectonic environment of the northern margin of the South China Sea. The Gaofeng and Baocheng intrusions are composed mainly of medium- to fine-grained biotite adamellite (Baocheng) and granodiorite (Gaofeng). The two intrusions yielded U-Pb LA-ICP-MS zircon ages of $107.7 \pm 6.1 \mathrm{Ma}$ (Gaofeng) and 105.8 $\pm 2.4 \mathrm{Ma}$ (Baocheng). Regarding the major elements, the Gaofeng and Baocheng intrusions had medium $\mathrm{Si}$ and alkali contents and high $\mathrm{Ca}, \mathrm{Mg}$, and $\mathrm{Al}$ contents, with an aluminum saturation index of 0.95-1.03 and 1.05-1.30. The trace element and rare earth element (REE) characteristics showed that the two intrusions have intense heavy REE/light REE (HREE/LREE) fractionation, LREE enrichment, HREE depletion, and weak negative Eu anomalies. The intrusions were enriched in high field-strength elements and depleted in large ion lithophile elements. These geochemical characteristics indicate that the Hainan Province was in a tectonic subduction environment in the late Yanshanian period. Multiple geochemical characteristics demonstrate that the granites in the Hainan Province were formed by a different mechanism and in a different setting from those in Fujian and Zhejiang. The late Mesozoic granites of Fujian and Zhejiang were formed by the Western Pacific subduction. However, Hainan Island was under an arc environment formed by the northward subduction of the Tethyan-South China Sea during the Cretaceous leading to emplacement of the Gaofeng and Baocheng intrusions.
\end{abstract}

Keywords: Tethyan-South China Sea, Subduction, Zircon U-Pb age, Geochemistry dykes were formed in an intraplate extensional environment, which, together with Cretaceous basic dykes in the coastal region of northern Guangdong and Fujian, indicated that southeastern China experienced an extensional tectonic environment during the Cretaceous period. The current hypotheses for the formation of late Mesozoic igneous rocks in Hainan Island are extensional thinning, post-arc extension, and intraplate anorogenic movement (TANG, 2014; JIA et al., 2010; YUN et al., 2004; LI et al., 2000; YANG et al., 1989). However, a previous study observed that Cretaceous andesites (QIANG, 2016) in the Hainan Province and detrital zircons from the Lumuwan Formation in the Ledong basin showed signatures of a continental-margin arc (TANG, 2014). We collected samples from the Gaofeng and Baocheng intrusions, and performed U-Pb LA-ICP-MS zircon dating and total-rock geochemical analysis to obtain a clear understanding of the geotectonic setting represented by the late Mesozoic rocks on Hainan Island.

\section{GEOLOGIC SETTING AND SAMPLING LOCATION}

This study focused on the Gaofeng and Baocheng intrusions (Table 1), which are represented by granitic rocks collected from the two areas. The Gaofeng intrusion lies at the junction of the southern margin of the Wuzhishan depression belt and the northern margin of the South China Sea Platform in the first-order tectonic unit (i.e., the South China Fold System). The Gaofeng complex is a ring-like intrusion emplaced northward within the ceous basic dykes on Hainan Island, GE (2003) proposed that the spheric extension-thinning, basaltic magma underplating, and enriched mantle-derived basaltic magma related to oceanic crust subduction, which contributed heat and material to the formation and evolution of the granites. From a systematic study of Creta- 
Table 1. The sample co-ordinates of all samples processed in the study.

\begin{tabular}{|c|c|c|c|c|}
\hline Area & & & & \\
\hline Sample Number & YL501 & YL601 & YL701 & YL703 \\
\hline Location & $18^{\circ} 19^{\prime} 10.9^{\prime \prime} \mathrm{N}, \quad 109^{\circ} 19^{\prime} 51.7^{\prime \prime} \mathrm{E}$ & $18^{\circ} 21^{\prime} 15,9^{\prime \prime} \mathrm{N}, \quad 109^{\circ} 19^{\prime} 36.0^{\prime \prime} \mathrm{E}$ & $18^{\circ} 20^{\prime} 19.6^{\prime \prime} \mathrm{N}, \quad 109^{\circ} 19^{\prime} 41.0^{\prime \prime} \mathrm{E}$ & $18^{\circ} 20^{\prime} 19.0^{\prime \prime} \mathrm{N}, \quad 109^{\circ} 19^{\prime} 39.2^{\prime \prime} \mathrm{E}$ \\
\hline Area & & $\mathrm{Bac}$ & eng & \\
\hline Sample Number & SHY101 & SHY201 & SHY302 & SHY401 \\
\hline Location & $18^{\circ} 32^{\prime} 00.9^{\prime \prime} \mathrm{N}, \quad 109^{\circ} 50^{\prime} 21.2^{\prime \prime} \mathrm{E}$ & $18^{\circ} 31^{\prime} 55.8^{\prime \prime} \mathrm{N}, \quad 109^{\circ} 50^{\prime} 17.3^{\prime \prime} \mathrm{E}$ & $18^{\circ} 31^{\prime} 51.3^{\prime \prime} \mathrm{N}, \quad 109^{\circ} 50^{\prime} 19.2^{\prime \prime} \mathrm{E}$ & $18^{\circ} 31^{\prime} 41.8^{\prime \prime} \mathrm{N}, \quad 109^{\circ} 50^{\prime} 26.8^{\prime \prime} \mathrm{E}$ \\
\hline
\end{tabular}

Lower Cretaceous Lumuwan Formation. The Baocheng intrusion occurs in Baoting County in the southeastern Hainan Province, north of the Jiusuo-Lingshui structural belt, and is also a relatively obvious ring-like complex (Fig. 1). Previous research on the Gaofeng and Baocheng granites is limited, but concluded that the Baocheng rocks are granodiorites and the Gaofeng granites are monzogranites (Fig. 2).The distribution of the two rock masses generally occurs along an east-west axis, without any
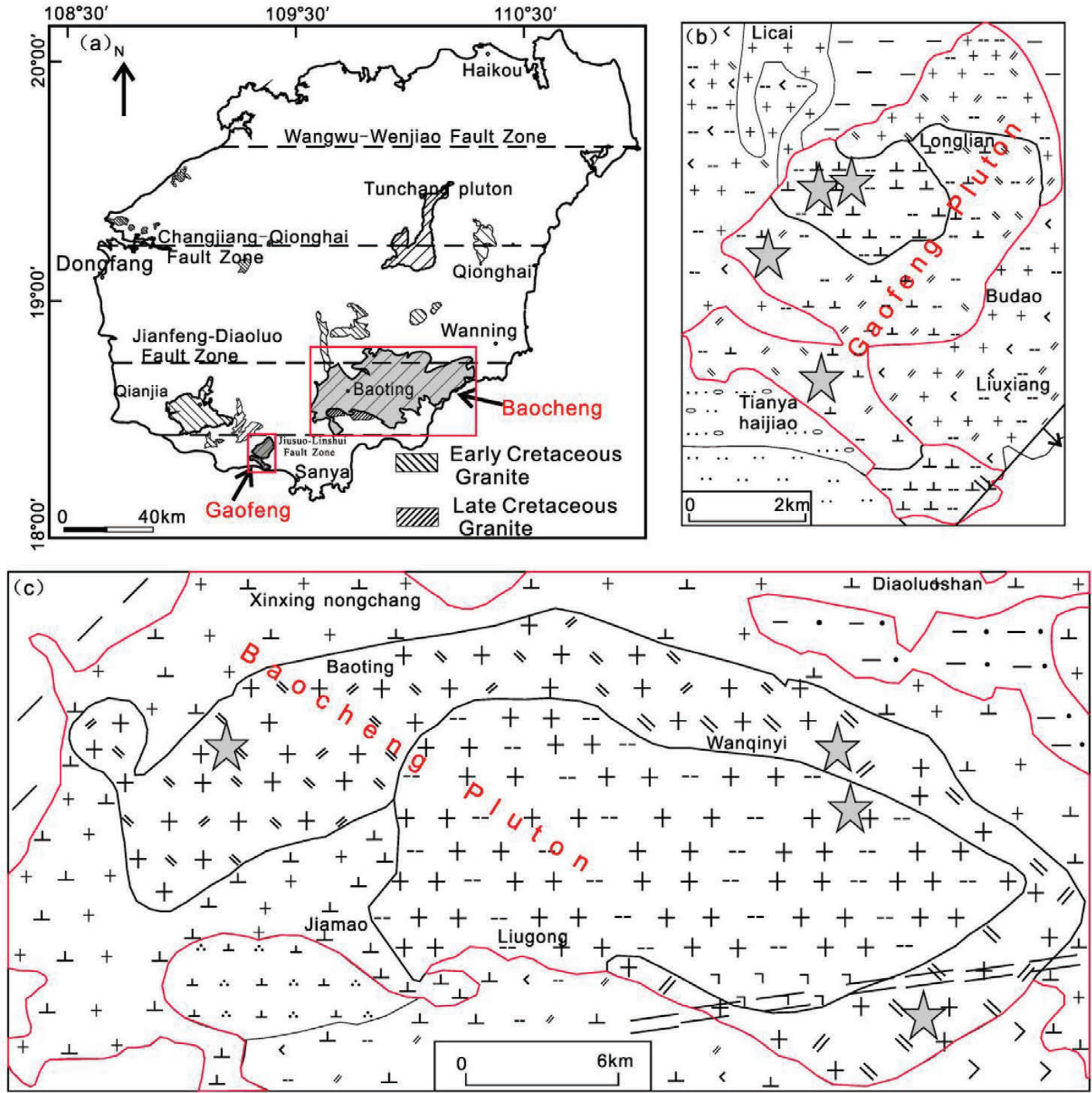

庰"

Figure 1. A simplified geological map of Hainan Island.1: Early Cretaceous Baoting Unit; 2: Early Cretaceous Baoyue Unit; 3: Early Cretaceous Liaociling Unit; 4: Early Cretaceous granite porphyry; 5: Early Cretaceous Liugong Unit; 6: Early Cretaceous Fushidou Unit; 7: Early Cretaceous Jiamao Unit; 8. Early Cretaceous Shuiding Unit; 9: Middle Triassic Chaopen Unit; 10: Middle Triassic Bushancun Unit; 11: Middle Triassic Jiewei Unit.; 12: Middle Permian Tongshi Unit; 13; Quaternary Basuo formation; 14: Coastal zone; 15: Deep Fault Zone; 16: Normal fault; 17: Sampling point. 


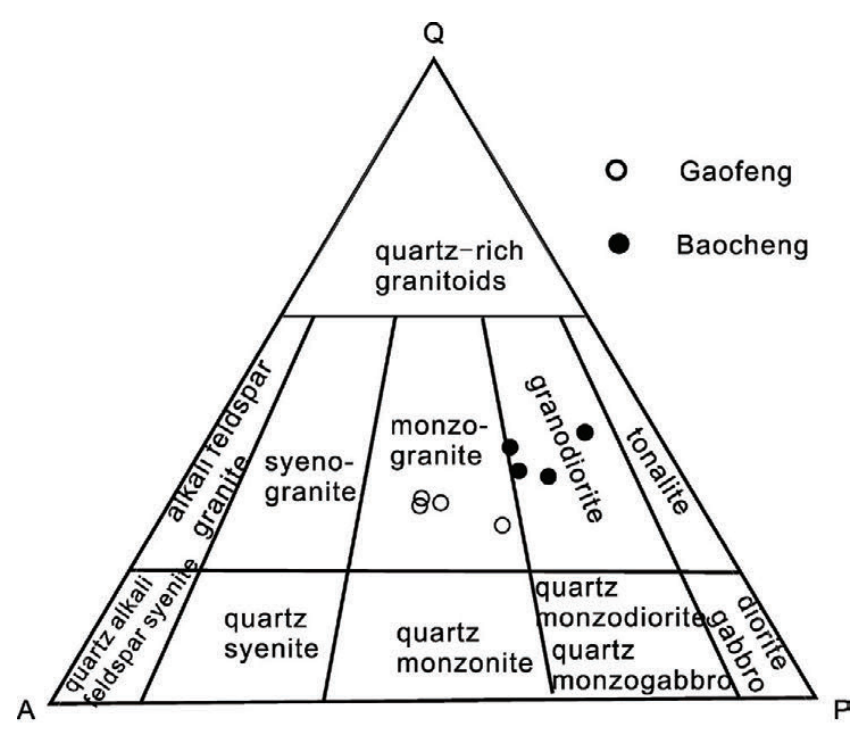

Figure 2. A Q-A-P diagram (after MANIAR et al., 1989).

primary banded structure. The central facies of the rock mass is dominated by monzogranite, which has a fine-medium porphy- roid texture. A small amount of granodiorite and granite can be observed; the marginal facies of the rock mass is dominated by granodiorite and quartz diorite, showing a medium-grained texture. From the centre to the margin, the lithological variation of the rock mass changes from monzogranite to granodiorite , quartz diorite, and the texture alters from fine-medium porphyroid to medium-grained fabric. There are intrusions in the Baocheng rock mass, composed of granite porphyry or granodiorite porphyry, and the contact zone between the rock mass and the surrounding rocks gradually changes to quartz porphyry or felsite porphyry. The dyke rocks are granite, aplite, lamprophyre and quartz veins.

Lithologically, the Cretaceous period mainly consists of sandstone, sandy conglomeratic, and mudstone. Lower Tertiary System formations from bottom to top include the Changliu, Liushagang, and Weizhou formations. Lacustrine deposits make up the majority of these formations. Neogene formations include the Xiayang Formation, Jiaowei Formation, Dengloujiao Formation, and the Wanglougang Formation. the majority of these sediments include neritic facies where the dominant lithology is coarse-grained sandstone and mudstone rich in glauconite, and foraminifera. Quaternary lithologies mainly consists of clay, tuff, pyroclastic rocks, and basalt.
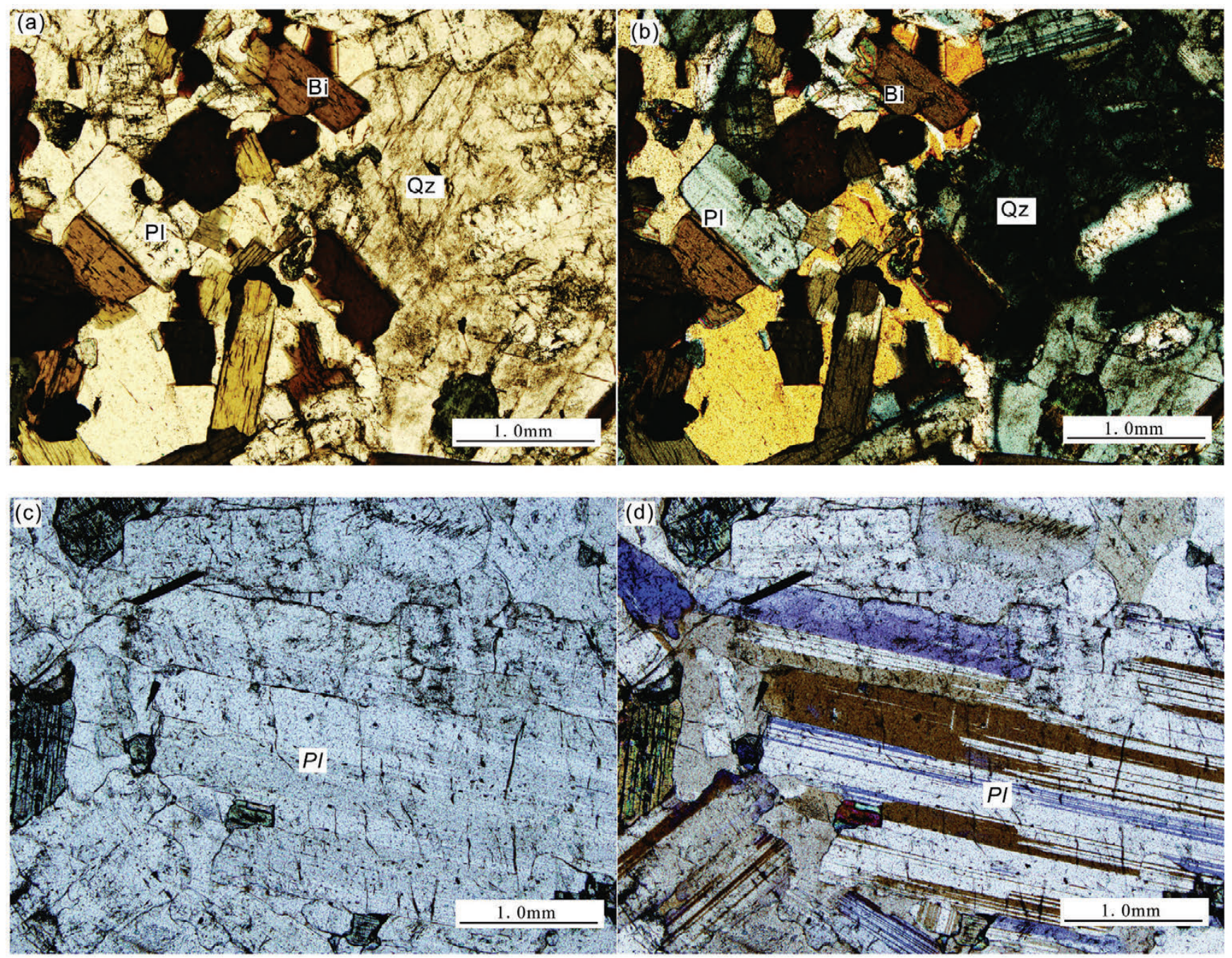

Figure 3. Photomicrographs of Gaofeng granite textures: (3a)Gaofeng (YL501) plane polarized light, and (3b)crossed polars (Granitic texture, Quartz shows xenomorphic granular texture, Plagioclase shows perthitic texture); (3c)Gaofeng (YL501) plane polarized light, and (3d)crossed polars (plagioclase show Carlsbad-albite compound twin). 

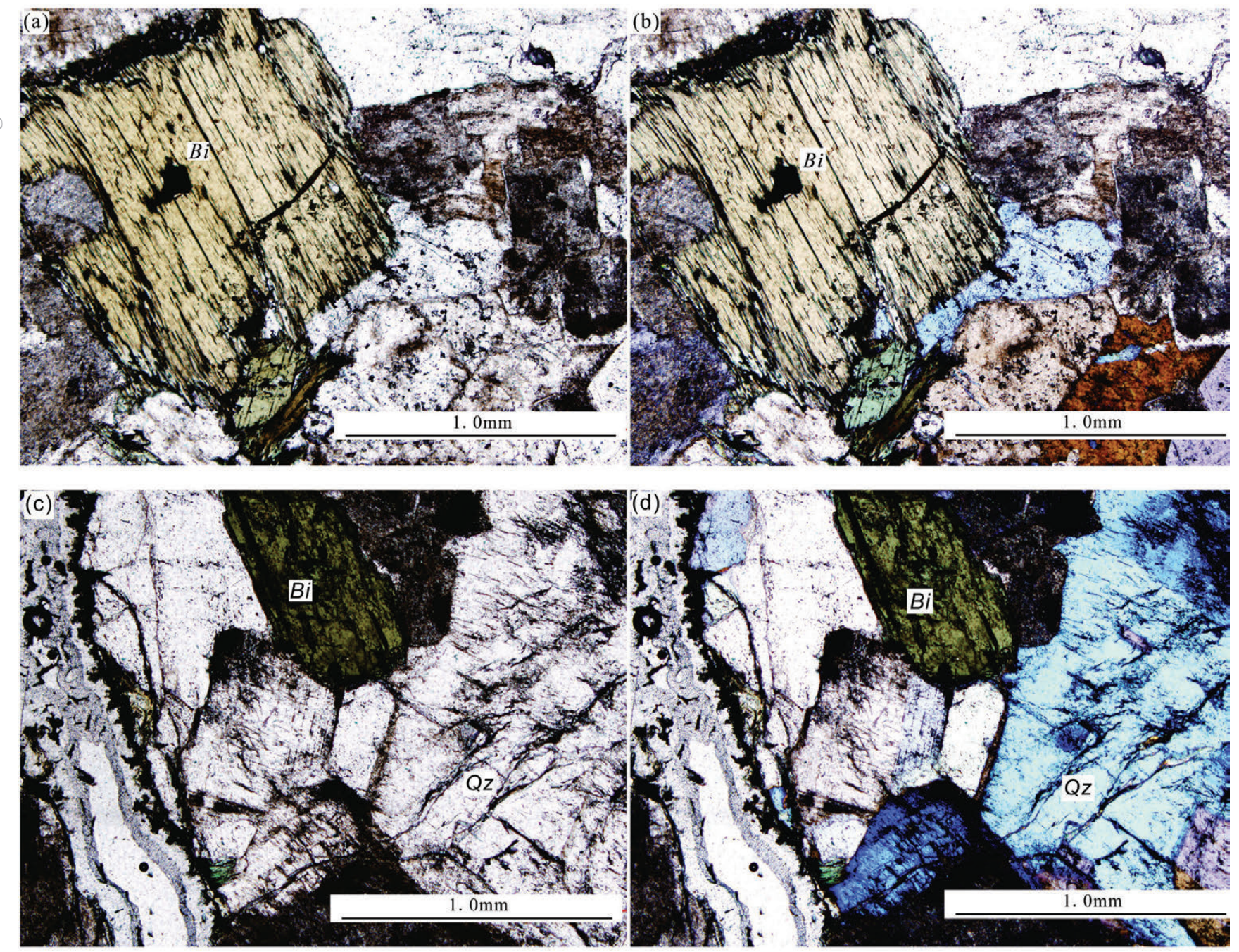

Figure 4. Photomicrographs of Baocheng granite textures: (4a)Baocheng (SHY401) plane polarized light, and (4b)crossed polars (biotite surround by plagioclase phenocryst); (4c)Baocheng (SHY401) plane polarized light, and (4d)crossed polars (porphyritic-like texture).

\section{PETROGRAPHY}

The granodiorite collected from the Gaofeng intrusion in the southern Hainan Province has a fine- to medium-grained granitic texture. In describing the main rock-forming minerals: potash feldspar is of reddish-brown colour and xenomorphic-platy in form, with crosshatched twins and ribbon texture characteristics; plagioclase is euhedral to subhedral-platy, with developed polysynthetic twins and sericitization; quartz is xenomorphic-granular in form with undulating extinction. Biotite, which appears dark green to yellow, is euhedral to subhedral-flaky, with one perfect cleavage and obvious pleochroism present. Accessory minerals predominantly include zircon and apatite. The main rock-forming minerals are quartz (20-30\%), potash feldspar (17-20\%), plagioclase (30-40\%), biotite (5-7\%), and hornblende (8-10\%) (Fig. 3).

The samples from the Baocheng intrusion are biotite adamellite. The rocks are light-grey in colour, massive with a mediumfine porphyritic-like texture. The main phenocrysts are potash feldspar with some quartz. Of the main rock-forming minerals, plagioclase is euhedral to subhedral-platy, with a ring-like texture. Most plagioclase grains occur as polysynthetic twins, and some are associated with strong sericitization. Potash feldspar is brownish-gray and xenomorphic-platy, with a typical ribbon texture. Quartz is anhedral granular, with undulating extinction. Hornblende is mostly idiomorphic to hypidiomorphic-granular, with moderate relief, two cleavage directions and pleochroism. It is dark green-light yellow in colour, with developed biotite reaction borders. Accessory minerals include apatite, zircon, and other opaque minerals. The mineral composition of the Baocheng intrusions is quartz (25-30\%), potash feldspar (8-40\%), plagioclase (5-25\%), and biotite (5-7\%), with hornblende observed locally (approximately 3\%) (Fig. 4).

\section{ANALYTICAL METHODS}

The element analysis was completed at the laboratory of the Hebei Institute of Regional Geology \& Mineral Survey. Major elements were measured with a Philips PW2404 X Ray Fluorescence Spectrometer (XRF), using the alkali-fusion cast-bead method. The National Standard Reference Material GBW07103 was used for quality monitoring during the measurement process. The nitric acid + hydrofluoric acid + perchloric acid open-vessel decomposition method was combined with nitric acid + hydrofluoric acid sealed-vessel decomposition to ensure complete dissolution of the samples. The equipment used for this assay was an ELEMENT I-type plasma mass spectrometer produced by the German company Finnigan-MAT, as well as the National Standard Reference Materials GBW07106 and GBW07312 for quality monitoring. The method is LA-ICP-MS (Inductively Coupled Plasma Mass Spectrometry). Representative samples YL701 and 
SHY401 were selected for LA-ICP-MS zircon U-Pb dating, and the dating samples corresponded to the samples for main and trace element analysis. The whole rock fresh sample was crushed to 80-120 mesh, then the zircon content was enriched by gravity and magnetic separation methods. Zircon grains were selected under binocular microscope, discharged onto the double-sided tape, placed in the mould and fixed with epoxy resin. After the zircon grains were consolidated, they were polished to expose the surface.

Zircon separation was performed at the Lab Center of the Hebei Institute of Regional Geology \& Mineral Survey. A laser ablation-inductively coupled plasma mass spectrometry (LAICP-MS) device was used for in situ zircon $\mathrm{U}-\mathrm{Pb}$ dating and trace element measuring at the State Key Laboratory of Continental Dynamics, Northwest University. A 193 nm ArF excimer laser with a spot size of $30 \mu \mathrm{m}$ was connected to an Elan61(X) DRCtype ICP-MS and used as the carrier gas for the ablation material. The Zircon Standard 91500 was used as the external standard to calibrate the isotopic fractionation during zircon $\mathrm{U}-\mathrm{Pb}$ isotopic dating. Using the USGS Reference Glass NIST 610 as the external standard and Si as the internal standard, quantitative calculations were performed to assay the zircon trace-element content. The 91500 + NIST 610 standard zircon was measured once for every six sample spot measurements. Specific details of the laboratory processes are provided in YUAN et al. (2003). U-Pb age concordia plots of zircon samples and an age-weighted average calculation were both determined with Isoplot (Ver. 3) (LUDWIG, 2003).

\section{RESULTS}

\subsection{ZIRCON U-Pb AGES}

Eight concordant ages were obtained from the Gaofeng intrusion (YL701), and nine from the Baocheng intrusion (SHY401). The analytical results are listed in Table 2. Most zircons from the two intrusions were idiomorphic to hypidiomorphic-columnar, with clean and smooth crystal surfaces. In general the crystals had a length/width ratio of 2:1, but some individual crystals were up to 3:1. Cathodoluminescence images demonstrated that the zircons from both intrusions displayed clear concentric zoning, with $\mathrm{Th} / \mathrm{U}$ ratios of $0.36-0.93$ (Gaofeng) and 0.53-0.90 (Baocheng). As all ratio values were larger than 0.1 , these zircons were determined to be magmatic (BELOUSOVA et al., 2002). The Gaofeng intrusion had a weighted average age of $(107.7 \pm 6.1) \mathrm{Ma}$, and the Baocheng intrusion an age of (105.8 \pm 2.4$)$ Ma, which may represent the formation ages of the two intrusions (Fig. 5-6).

\subsection{RESULTS}

\subsubsection{MAJOREEMENTS}

Table 3. lists the chemical compositions of the representative samples from the Gaofeng and Baocheng intrusions. Granitic rocks from the Gaofeng intrusion had a $\mathrm{SiO}_{2}$ content of 65.90$72.42 \%$, total alkali content $\left(\mathrm{K}_{2} \mathrm{O}+\mathrm{Na}_{2} \mathrm{O}\right)$ of $7.29-8.13 \%$, and $\mathrm{K}_{2} \mathrm{O} / \mathrm{Na}_{2} \mathrm{O}$ ratios of $1.27-1.6$. On the total alkali-SiO $\mathrm{S}_{2}$ diagram for intrusive rocks (MIDDLEMOST, 1994; Fig. 7) all samples fell within the granite field, with the exception of sample YL501 that fell outside the granodiorite domain. On the $\mathrm{SiO}_{2}-\mathrm{K}_{2} \mathrm{O}$ diagram, all samples were within the high-K calc-alkaline series domain. On the A/CNK-A/NK diagram, most of the samples were within the metaluminous rock domain (Fig. 8a). The aluminum saturation index was $0.95-1.03$, and the Rittmann Serial Index $(\sigma)$ ranged from 2.26 to 2.32 . The magma differentiation index (DI)

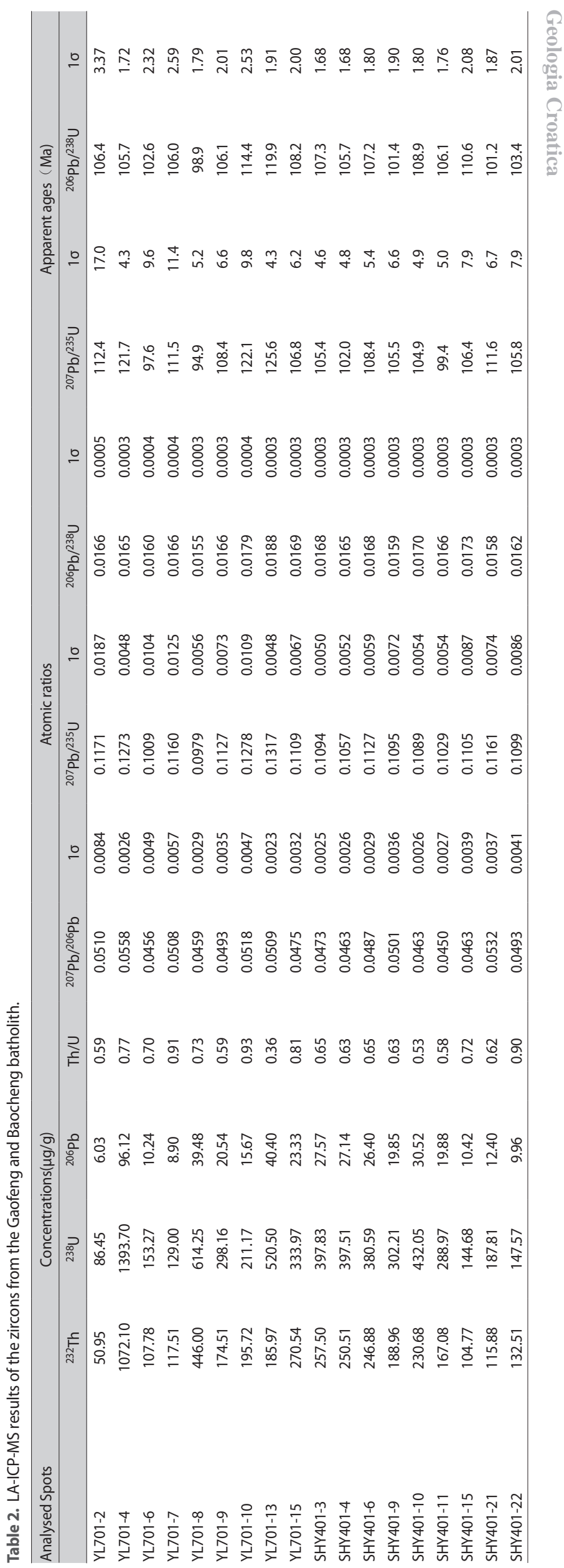




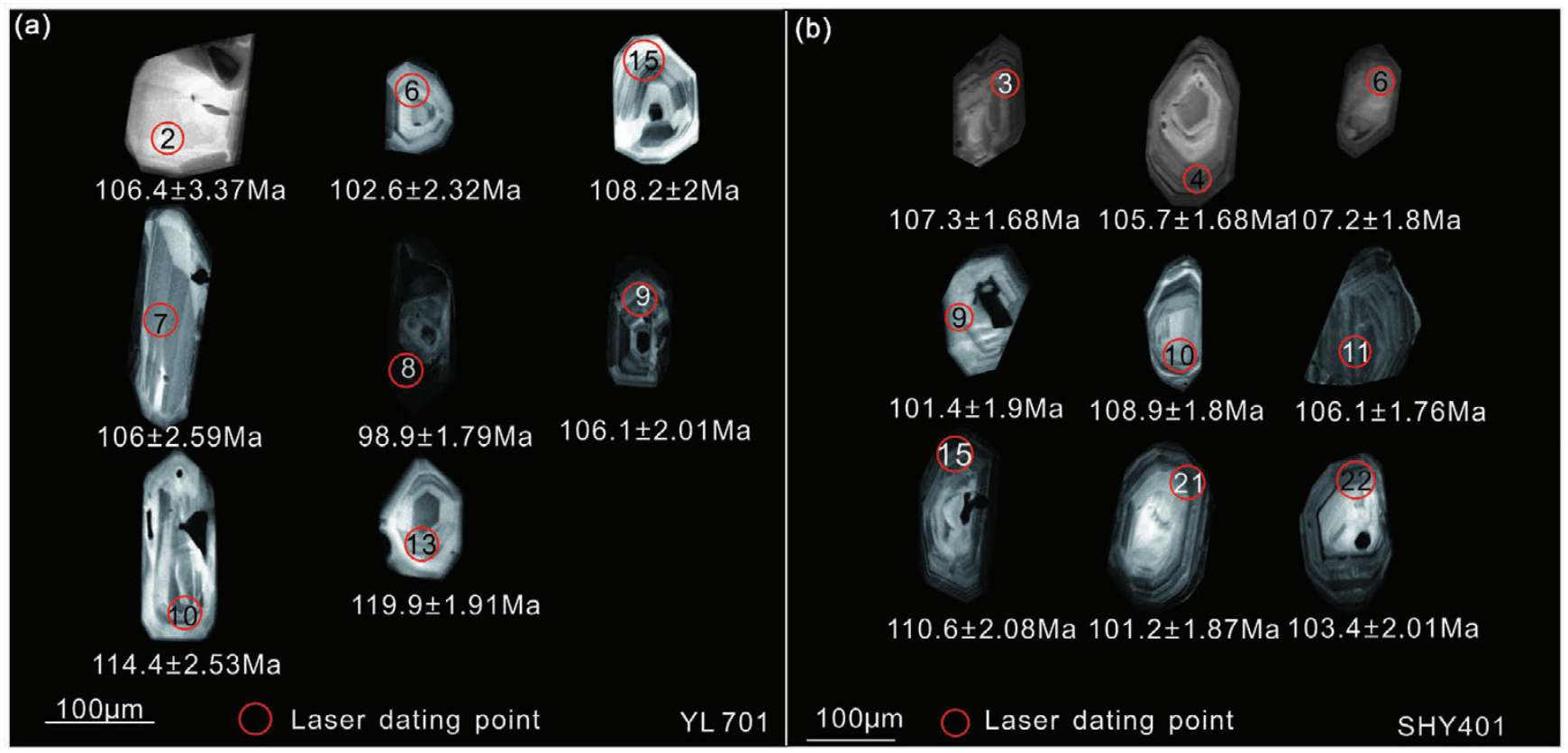

Figure 5. Cathodoluminescent images and spot analysis points of zircon crystals from the Hainan granite (a) Oscillatory zircon from the Gaofeng granite (b) Oscillatory zircon from the Baocheng granite.
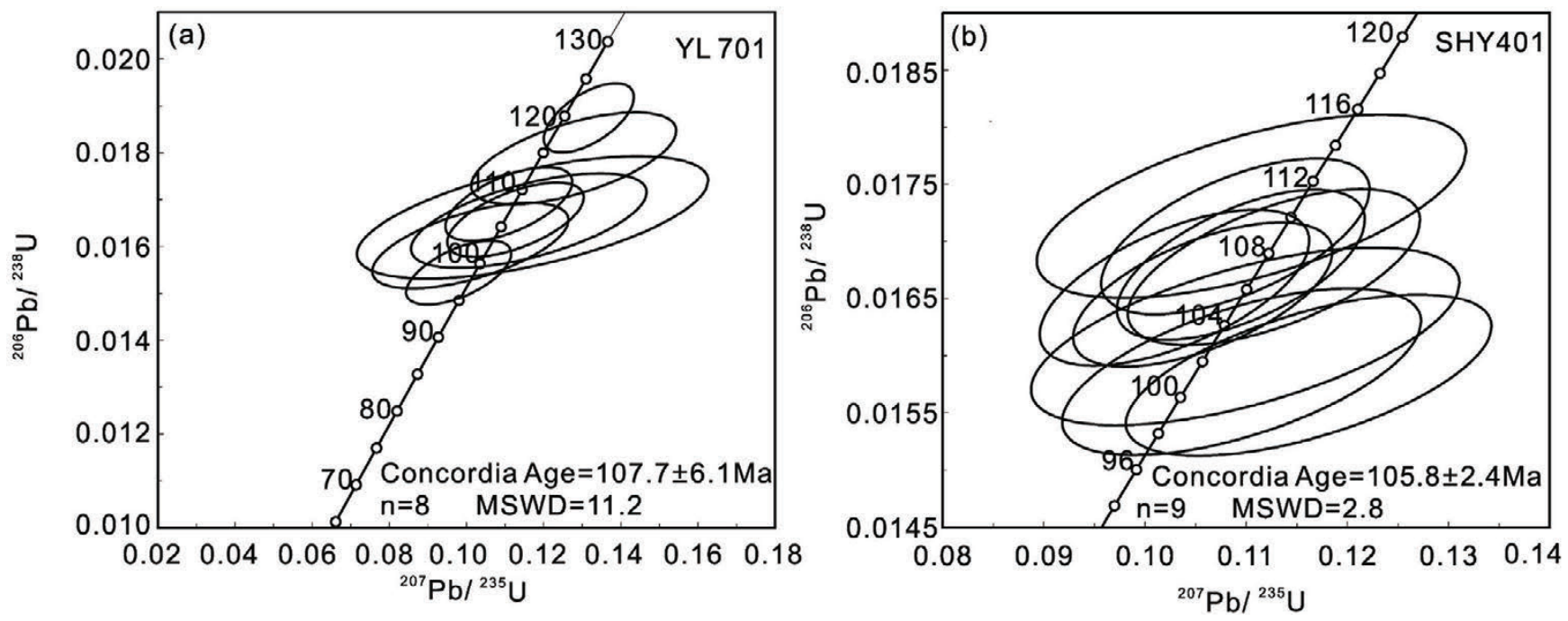

Figure 6. Results of in situ zircon ${ }^{206} \mathrm{~Pb} /{ }^{238} \mathrm{U}$ age dates (a) Gaofeng granite (b) Baocheng granite.

value is between 73-86, the solidification index (SI) value is 4-12, and the Harker diagram (Fig. 6) shows that $\mathrm{SiO}_{2}$ is significantly negatively correlated with $\mathrm{FeO}, \mathrm{MgO}, \mathrm{CaO}, \mathrm{Al}_{2} \mathrm{O}_{3}, \mathrm{P}_{2} \mathrm{O}_{5}$ and $\mathrm{TiO}_{2}$ rocks may undergo crystallization differentiation evolution.

The Baocheng granites had a $\mathrm{SiO}_{2}$ content range of 69.37$72.42 \%$, total alkali content $\left(\mathrm{K}_{2} \mathrm{O}+\mathrm{Na}_{2} \mathrm{O}\right)$ of $6.8-7.54 \%$, and $\mathrm{K}_{2} \mathrm{O} / \mathrm{Na}_{2} \mathrm{O}$ ratios of $1.03-1.34$. On the total alkali-SiO $\mathrm{S}_{2}$ diagram for intrusive rocks (MIDDLEMOST, 1994; Fig. 7), all samples fell within the granite field. All samples were plotted within the high-K calc-alkaline series domain on the $\mathrm{SiO}_{2}-\mathrm{K}_{2} \mathrm{O}$ diagram (Fig. 8a). The A/CNK-A/NK diagram shows that the majority of the samples fell within the weakly peraluminous rock domain (Fig. 8b). The aluminum saturation index was $1.05-1.30 \%$, and the Rittmann Index was $\sigma=1.75-1.95$.

\subsubsection{TRACEEFMENTS}

Total rare earth element ( $\sum$ REE) contents were 204.45-236.48 $\mu \mathrm{g} / \mathrm{g}$ in the Gaofeng intrusion, and lower $(94.35-192.30 \mu \mathrm{g} / \mathrm{g})$ in the Baocheng intrusion. The $(\mathrm{La} / \mathrm{Yb})_{\mathrm{N}}$ values of the granitic rocks from the two intrusions were 10.32-15.89 and 17.56-31.13, respectively. These values indicate a high degree of heavy REE/ light REE (HREE/LREE) fractionation and LREE enrichment. The Gaofeng intrusion had $\delta$ Eu values of $0.52-0.66$ and a moderately negative Eu anomaly; the Baocheng granitic rocks had $\delta \mathrm{Eu}\left(\mathrm{Eu} / \mathrm{Eu}^{*}=\mathrm{Eu}_{\mathrm{N}} / \sqrt{\mathrm{Sm}_{\mathrm{N}} / \mathrm{Gd}_{\mathrm{N}}}\right)$ values of $0.77-0.88$, and show a weak negative Eu anomaly. The REE partition pattern shows that the Gaofeng and Baocheng intrusions have basically consistent REE partition patterns of right-deviating curves (Fig. 10a).

The incompatible-elements spider diagram normalized on a primitive mantle (Fig. 10b) shows that both the Gaofeng and Baocheng intrusions were enriched in large ion lithophile elements (LILE), but depleted in high field-strength elements (HFSE). Enrichment of large ion lithophile elements (LILE) such as Rb, Ba, $\mathrm{Sr}$ and $\mathrm{K}$, and loss of high field strength elements such as $\mathrm{Nb}, \mathrm{Ta}$, $\mathrm{P}$ and $\mathrm{Ti}$ (Fig. $7 \mathrm{~b}$ ), Rb/Sr value $0.32-0.80, \mathrm{~K} / \mathrm{Rb}$ value $180-250$, is similar to the typical characteristics of granites related to sub- 


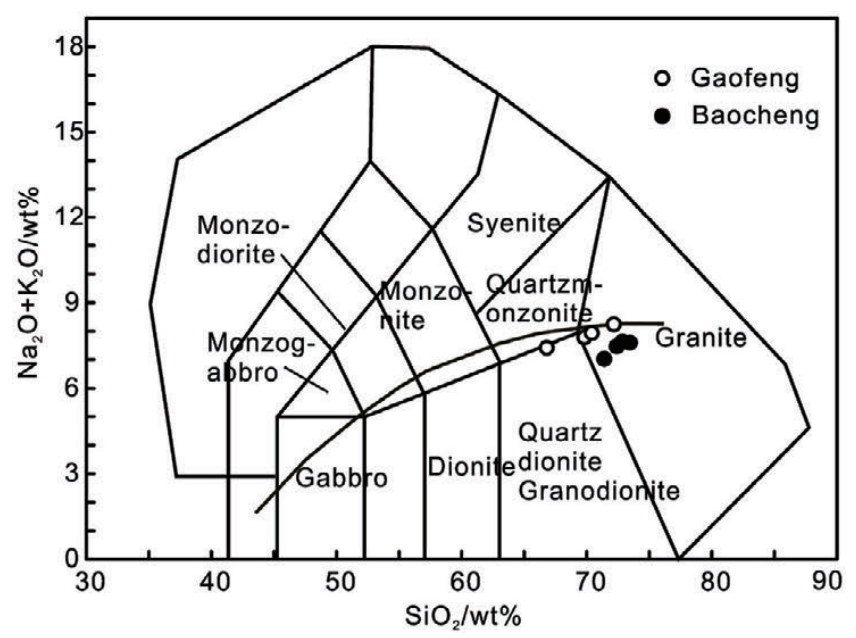

Figure 7. $\mathrm{SiO}_{2}$ versus $\mathrm{K}_{2} \mathrm{O}+\mathrm{Na}_{2} \mathrm{O}$ diagram for intrusive rocks (MIDDLEMOST, 1994; IRVINE \& BARAGAR, 1971).

duction. It also indicates that there may be fractionation crystallization of apatite, Ti-rich minerals, rutile and so on during magma evolution. On the mid-oceanic ridge standardized dia- gram, the Gaofeng and Baocheng intrusions were relatively similar to Chilean granites (PEARCE et al., 1984), which is typical of an active continental-margin environment (Fig. 10c). The Sr content of the Gaofeng rock mass is 191-356 ppm, averaging $277.25 \mathrm{ppm}$. The Yb content is 2.35-2.93 ppm, (average 2.57 ppm) and the Y content is 23.2-27.9 ppm (average 24.68 ppm); the Sr content of Baocheng rock mass is relatively higher at 327$431 \mathrm{ppm}$ with an average of $396.75 \mathrm{ppm}$, and the $\mathrm{Yb}$ content is relatively lower at $0.75-1.75 \mathrm{ppm}$, (average $1.06 \mathrm{ppm}$ ). The Y content is relatively lower at 5.6-17.5 ppm, (average $9.5 \mathrm{ppm}$ ). Peak $\mathrm{Sr} / \mathrm{Y}$ value ranges from 8.23-15.15, average 11.3, Sr/Yb value 23.2-27.9, average 24.68; Baocheng Sr/Y value 23.54-76.96, average 50.05, Sr/Yb value 235.43-552.56, average 414.68. The overall characteristics show higher $\mathrm{Sr}$ and lower $\mathrm{Yb}, \mathrm{Y}$ content and higher $\mathrm{Sr} / \mathrm{Yb}, \mathrm{Sr} / \mathrm{Y}$ ratios. The characteristics of high $\mathrm{SiO}_{2}$, high $\mathrm{Al}_{2} \mathrm{O}_{3}, \mathrm{Mg}^{\#}$ value is 41-44, high $\mathrm{Sr}$, low $\mathrm{Y}$ and $\mathrm{Yb}$, high $\mathrm{Sr} / \mathrm{Y}$ and $\mathrm{Sr} / \mathrm{Yb}$, and weak Eu negative abnormity are similar to those of adakites representing the source of the subduction slab (STERN \& KILIAN, 1996; WANG et al., 2006; SHEPPARD et al., 2001), which is also consistent with the characteristics of active continental margins represented by rare earth and trace elements.
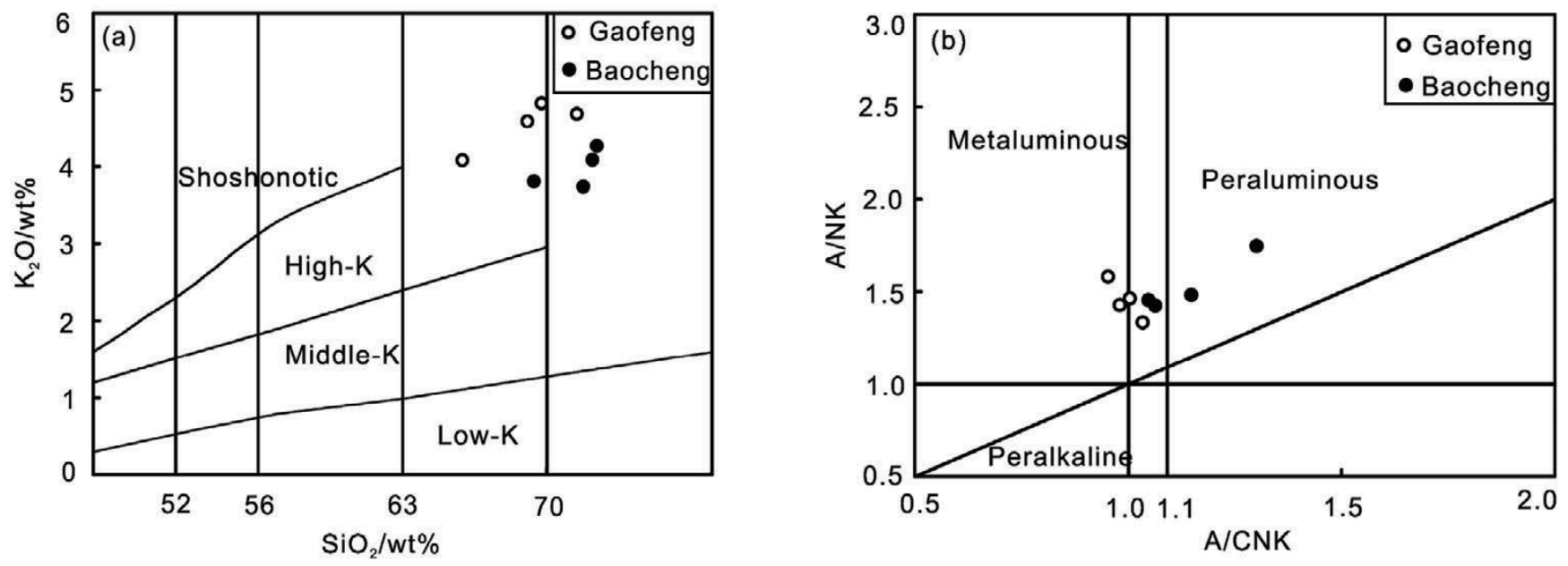

Figure 8. The classification of the Gaofeng and Baocehng granites: (a) $\mathrm{SiO}_{2}$ versus $\mathrm{K}_{2} \mathrm{O}$ diagram (after PECCERILLO \&TAYLOR, 1976); (b) A/CNK versus A/NK diagram (after MANIAR \& PICCOLI, 1989).
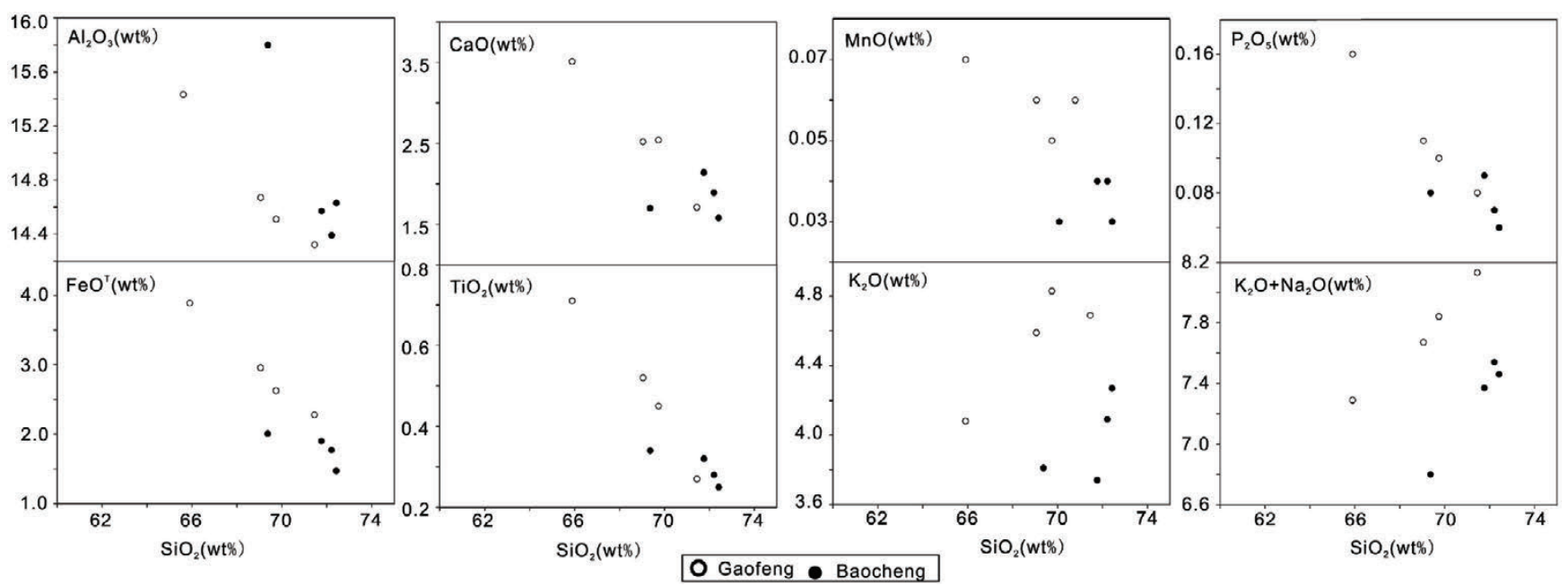

Figure 9. Harker diagram of the Gaofeng and Baocehng granites. 

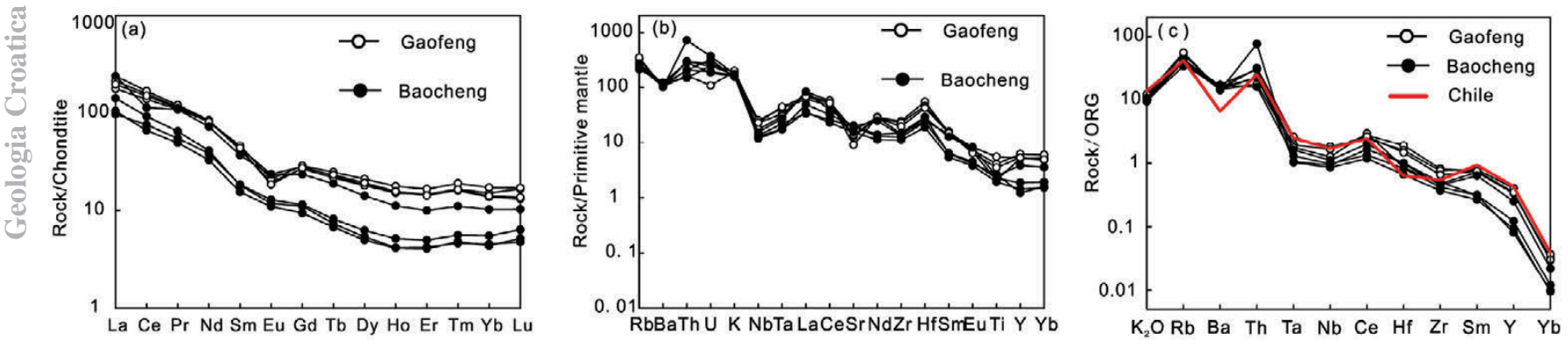

Figure 10. Normalized diagrams of the Gaofeng and Baocehng granites: (a) REE patterns; (b) incompatible element spidergrams; (c) Ocean Ridge Granite (ORG) granite normalized patterns (Chondrite REE values and primitive mantle-normalized values from SUN \& MCDONOUGH (1989); KHOSHNOODI et al. (2017); ORG and Chile granite values from PEARCE et al. (1984).
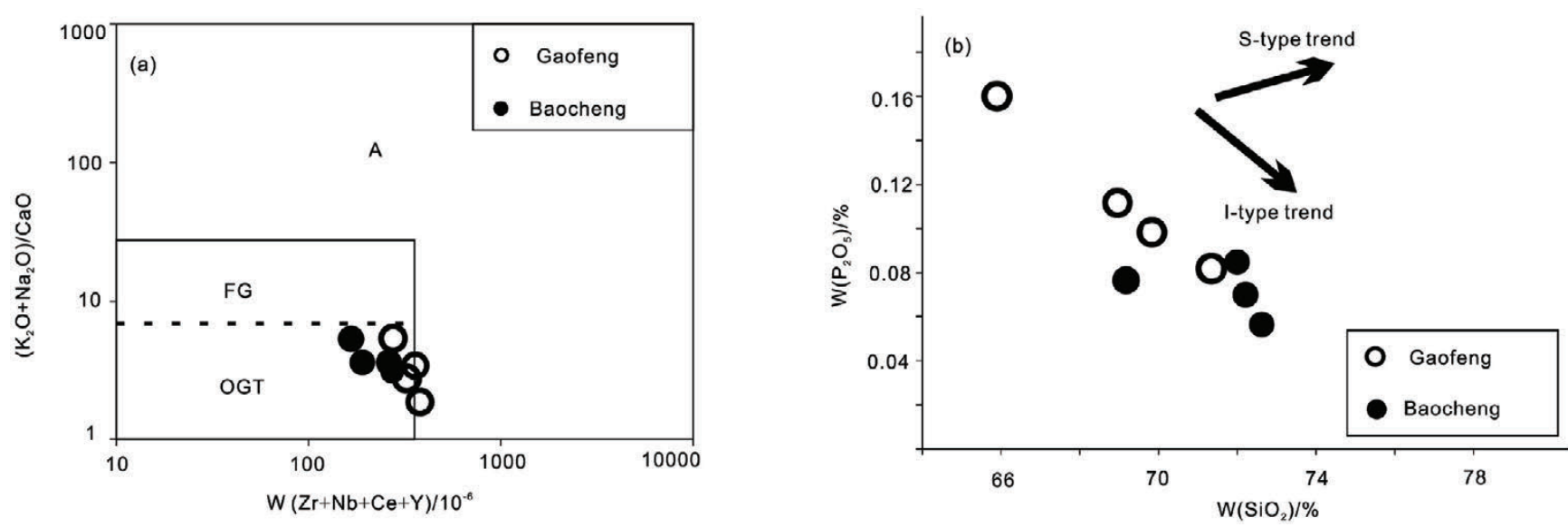

Figure 11. Sample classification using diagrams of (a) $(\mathrm{Zr}+\mathrm{Nb}+\mathrm{Ce}+\mathrm{Y})$ vs. $\left(\mathrm{K}_{2} \mathrm{O}+\mathrm{Na}_{2} \mathrm{O}\right) / \mathrm{CaO}$ (WHALEN et al., 1987); (b) $\mathrm{P}_{2} \mathrm{O}_{5}$ vs. SiO $\mathrm{S}_{2}$ variation (CHAPPELL \& WHITE, 1992).

\section{DISCUSSION}

\subsection{ROCK TYPE AND GENESIS}

The I-, S-, M-, and A-type classification scheme (PITCHER, 1983) has been generally accepted as a classification scheme for granites. M-type granites that formed during mantle magma evolution are very rare, and represent an oceanic island-arc tectonic environment. Considering the regional tectonic setting of Hainan Island during the Cretaceous, M-type granites are not represented in the granites studied here. Hence, the granites of the southern Hainan Province are mainly represented by I-, S-, and A-types. Fig. 11a shows that most of the samples are undifferentiated I-, $\mathrm{S}$-, and A-types. I- and S-type granites can be discriminated using $\mathrm{P}_{2} \mathrm{O}_{5}$ and $\mathrm{P}_{2} \mathrm{O}_{5}-\mathrm{SiO}_{2}$ diagrams (Fig. 11b). The $\mathrm{P}_{2} \mathrm{O}_{5}$ content decreases with increasing $\mathrm{SiO}_{2}$ content, resulting in a negative correlation; this relationship is consistent with the evolution of Itype granites, and is markedly different from S-type granites.

The major element characteristics of the granites from this study indicate that these rocks are metaluminous to weakly peraluminous, with obvious HREE/LREE fractionalization, LREE enrichment, and HREE depletion. The trace element characteristics included LILE enrichment and a depletion of Ta, Nb, and Ti and other HFSE, suggesting that the granites had signatures of island-arc granites. In addition, laboratory petrological research implied that partial melting of intermediate-basic rocks in the crust formed metaluminous granitoids with a more basic chemical composition (WOLF et al., 1994; BEARD et al., 1991; JOHANNES et al., 1996; SISSON et al., 2005). The source rocks of these granitoids may have been derived from partial melting of island-arc volcanic rocks, or comagma of island-arc volcanic rocks.

\subsection{PETROGENESIS AND SOURCE CHARACTERISTICS}

It is a widely accepted fact in the literature that I-type granite is a product of crust-mantle mixed source magmatism (BERGANTZ, 1989; PETFORD \& CRUDEN, 2000; ZHOU \& LI, 2000; ANNEN \& SPARKS, 2002). The Gaofeng and Baocheng granites are characterized by their high Sr, low $\mathrm{Yb}$ and $\mathrm{Y}$, high $\mathrm{Sr} / \mathrm{Yb}$ and $(\mathrm{La} / \mathrm{Yb}$ ) $\mathrm{n}$ ranging from $15-31 \mathrm{ppm}$ which is very similar to adakites (WANG et al., 2012; JIA et al., 2010). Mantle source characteristic identification charts are shown in Fig. 12a-c. It can be seen in Fig. 12a-c, that the $\mathrm{SiO}_{2}-\mathrm{Mg}^{\#}$ variable diagram, $\mathrm{SiO}_{2}-\mathrm{MgO}$ variable diagram, and $\mathrm{Ba} / \mathrm{Th}-\mathrm{Nb} / \mathrm{Zr}$ variable diagram show that the source area is related to plate subduction. Identification of hornblende, the hydrous mineral in the sample, confirms that the studied rocks originate from subducted plates.

There are two possible models for genesis of I-type granites from the mantle (QIU et al., 2008). The first model includes mixing between the mantle derived magma and felsic magma from the crust. The second model is where the mantle-derived magma first intrudes into the crust to form the primary crust. Then, this mixed crustal rock which consists of both primary crust and the ancient basement crust is partially melted under the influence of later thermal events. The $\mathrm{Nb} / \mathrm{La}$ ratios of the Gaofeng and Baocheng granites described here are close to the crust except for the samples which occur in the plate melting zone as presented in Fig.12a-b. The rest of the samples are distributed near the component lines affected by the AFC indicating that these granites have not originated directly from melting of a mantle-derived subduction plate. This is more consistent with the second model as explained above. These findings also confirm similar reports 

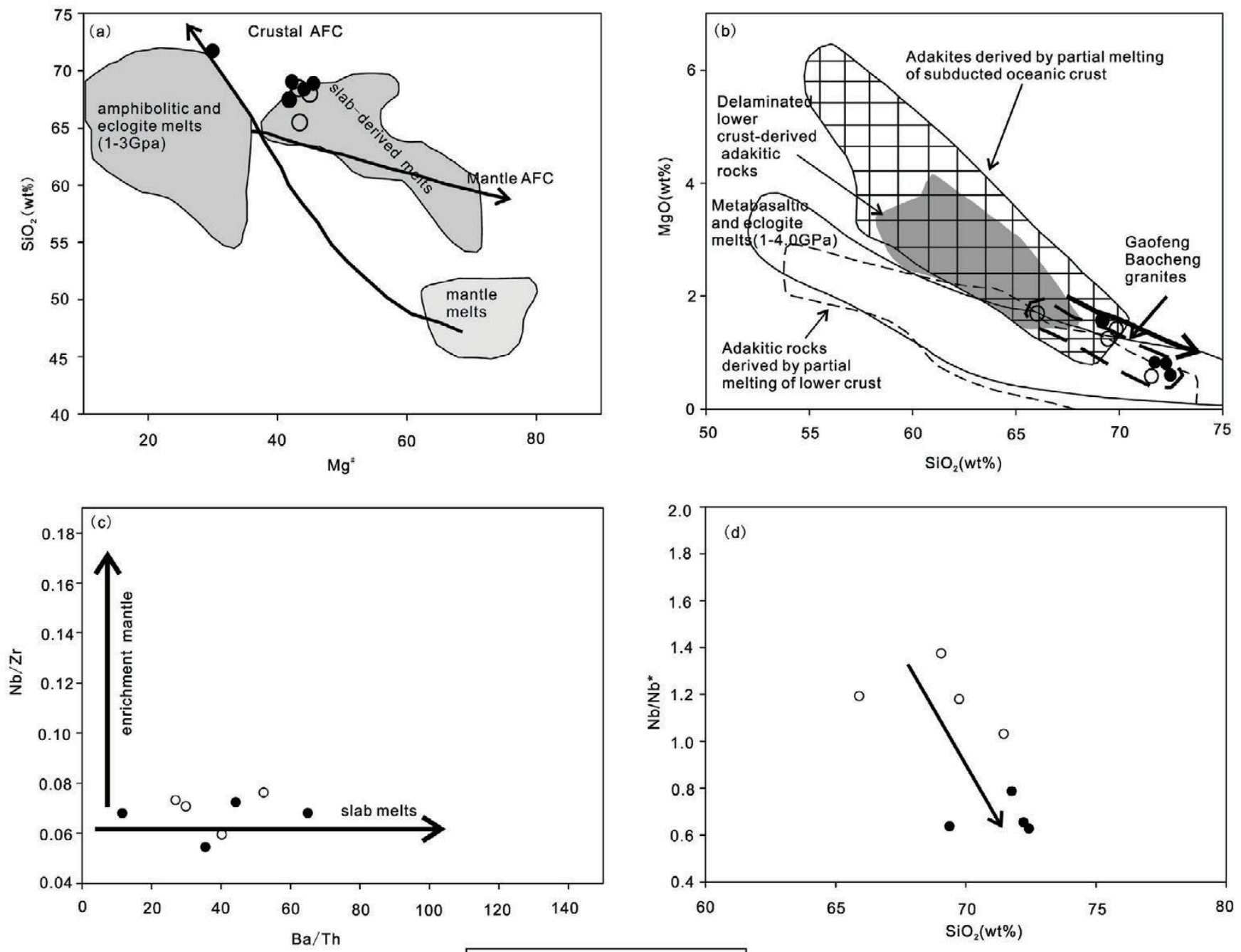

$$
\text { ○ Gaofeng Baocheng }
$$

Figure 12. The characteristics of magma source and evolution: (a) $\mathrm{Mg}^{\#}-\mathrm{SiO}_{2}$ diagram (after STERN \& $\mathrm{KILIAN}_{1}$ 1996); (b) $\mathrm{SiO}_{2}-\mathrm{MgO}$ diagram (after WANG et al., 2006); (c) $\mathrm{Ba} / \mathrm{Th}-\mathrm{Nb}$-Zr diagram (ABRATIS, 2001); (d) $\mathrm{SiO}_{2}-\mathrm{Nb} / \mathrm{Nb}^{*}$ diagram (after MA et al., 2004).

previously published in the literature (PITCHER et al., 1985; WU et al., 2003b).

According to GE et al. (2003) and TANG et al. (2014), basic intrusive rocks with strong arc features in the same area and in the same geological time period (i.e., early and late Cretaceous in the southern of Hainan) have the same geochemical characteristics as those of the Gaofeng and Baocheng intrusive rocks. These similar characteristics include high Sr-rich K, high K/Tilow Ti, low Y and $\mathrm{Yb}$, no negative Eu anomalies, $\mathrm{Rb} / \mathrm{Sr}, \mathrm{Nb} / \mathrm{La}$ ratios, enrichment of large ion lithophile elements and high field strength element loss. Basic intrusive rocks originated from the melting of subducted plates (TANG et al., 2014). It can be inferred that the mantle-derived components of the Gaofeng and Baocheng granite magmas may have similar or identical source areas with the basic intrusive rocks. The primary crust and the basic intrusive rocks mentioned above in the second model may be products of the same source area. Their only difference is the depth of intrusion. According to TANG et al. (2014), the basic intrusive rocks are derived from the garnet phase. It is speculated here that the primary crust originates from the garnet phase.

Magma Differentiation Index (DI) and Solidification Index (SI) values of the Gaofeng and Baocheng granites range from 73 to 86 and from 4 to 12, respectively. In addition, $\mathrm{SiO}_{2}$ is negatively correlated with $\mathrm{FeO}, \mathrm{MgO}, \mathrm{CaO}, \mathrm{Al}_{2} \mathrm{O}_{3}, \mathrm{P}_{2} \mathrm{O}_{5}$, and $\mathrm{TiO}_{2}$. It can be concluded here that crystallization differentiation took place during magmatism. The negative anomalies between $\mathrm{Nb}$, Ta, $\mathrm{Ti}, \mathrm{P}$, and $\mathrm{SiO}_{2}$ are negatively correlated with $\mathrm{Nb} / \mathrm{Nb}^{*}$ $\left(\mathrm{Nb}^{*}=2 \mathrm{Nbn} /(\mathrm{Kn}+\mathrm{Srn})\right.$ (Fig. 12d). This indicates that the negative anomalies are mainly caused by crustal AFC (MA et al., 2004). The above characteristics confirm the occurrence of ilmenite, rutile, and apatite separation crystallization during magma evolution. The negative anomaly of Ba does not represent the separation and crystallization of potassium feldspar. This is because there is a positive correlation between $\mathrm{K}_{2} \mathrm{O}$ and $\mathrm{SiO}_{2}$ in the Huck diagram (Fig. 9) and there is only a slight negative anomaly of the Eu element. It is inferred from the insignificant negative Sr anomaly that there is no or little separation crystallization of plagioclase. This shows that there is little or no separation of potassium feldspar and plagioclase during magmatic evolution.

In summary, the characteristics and evolution process of the source area of the Gaofeng and Baocheng granites are as follows: The partially melted garnet phase affected by the subduction of plates intrudes into the bottom of the crust to form a primary crust with a higher basic composition. The mixed crust formed by the primary crust and the ancient crust partially melts to form a granitic magma. The mixed magma rises and emplaces in the crust with differential crystallization of minerals such as apatite, ilmenite, and rutile. 
Table 3. Major (wt\%) and trace element $(\mu \mathrm{g} / \mathrm{g})$ abundances of representative samples from the Gaofeng and Baocheng suites.

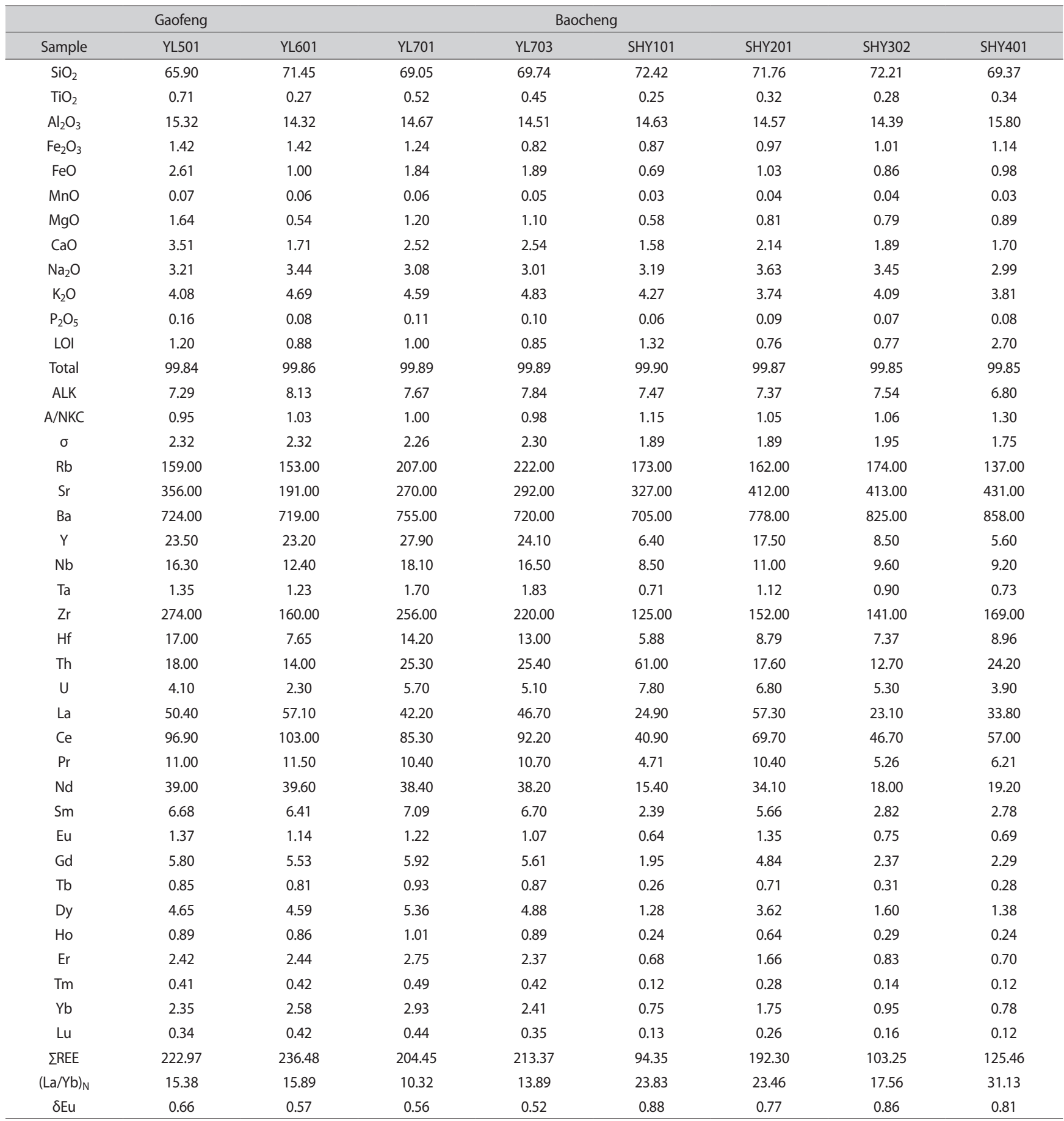

\subsection{TECTONIC SETTING}

The major element characteristics of the Gaofeng and Baocheng intrusions indicate the rocks are high-K calc-alkaline series. The source areas of high-K calc-alkaline series are related to previous subduction (LIEGEOIS et al., 1998). The trace-element spider diagram of the Gaofeng and Baocheng intrusions indicates typical negative $\mathrm{Nb}, \mathrm{Ti}$, and $\mathrm{Ta}$ anomalies, which are similar to the characteristics of island-arc granites. Similarly, the mid-oceanic ridge standardized diagram shows that the Gaofeng and Baocheng intrusions had trace element characteristics similar to those of active continental-margin rocks. On the Rb/30-Hf-Ta×3 diagram (Fig. 14), the Gaofeng and Baocheng intrusions were located within the volcanic-arc granite domain. Similarly, according to Pearce's granite tectonic setting discrimination diagram (Fig. 13), the Nb-Y, Ta-Yb,
$\mathrm{Rb}-(\mathrm{Y}+\mathrm{Nb})$, and $\mathrm{Rb}-(\mathrm{Yb}+\mathrm{Ta})$ trace elements discrimination diagrams demonstrate that the samples were volcanic-arc granites.

Some of the above features correspond to those of a continental margin arc as follows: Early Cretaceous andesite and rhyolite widely exposed in southern Hainan show typical continental margin arc characteristics (QIANG, 2016; HAN, 2017). The clastic compositions, chemical compositions and sedimentary structural characteristics of the Lower Cretaceous Lumuwan Formation and the Upper Cretaceous Baowan Formation all indicate that sedimentation took place in the continental margin arc setting. The age of the detrital zircon assemblage especially indicates that strong compression and uplift occurred at the turn of early and late Cretaceous in the southern Qiongnan area, and this tectonic activity lasted until the middle of the late Cretaceous 

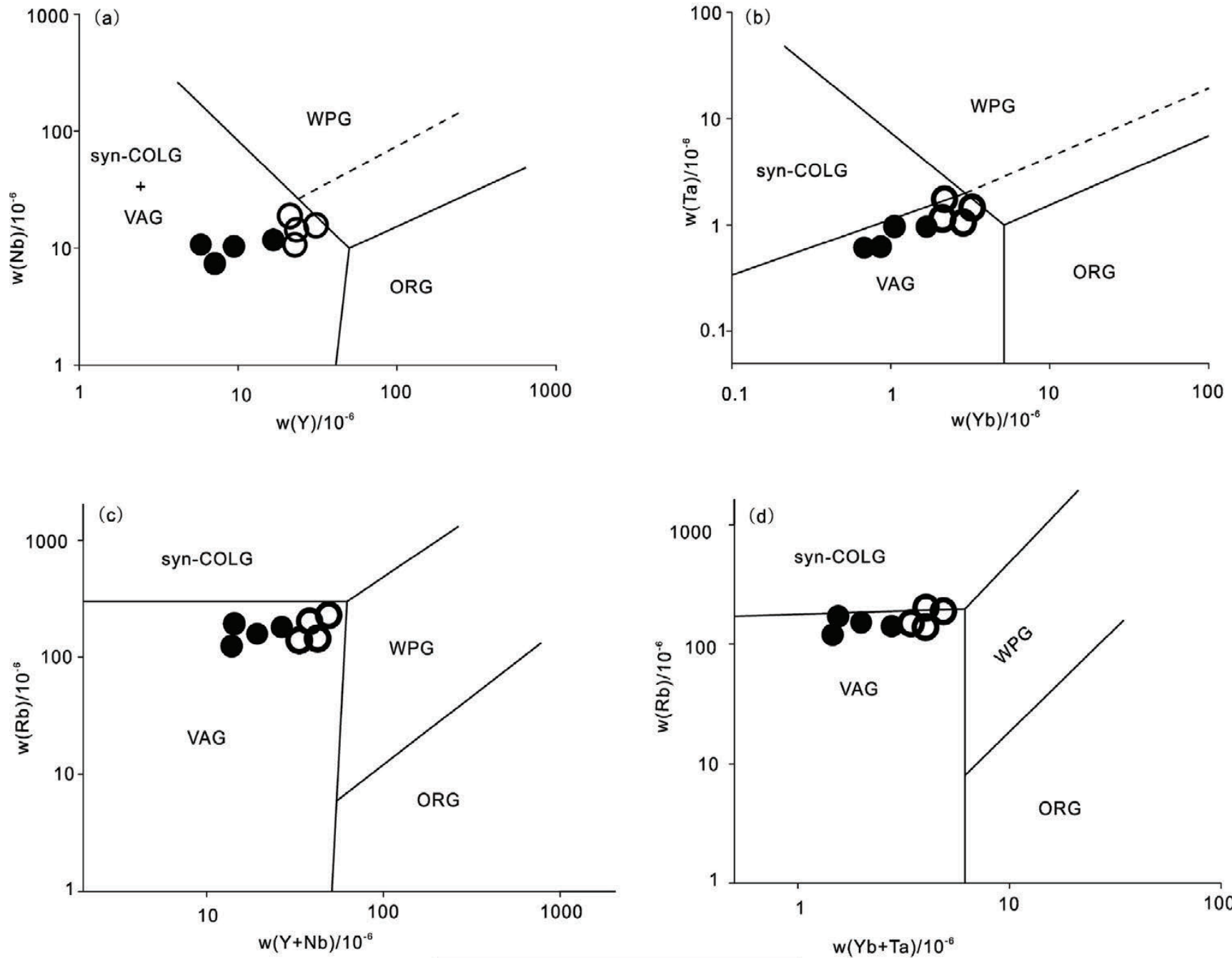

Gaofeng

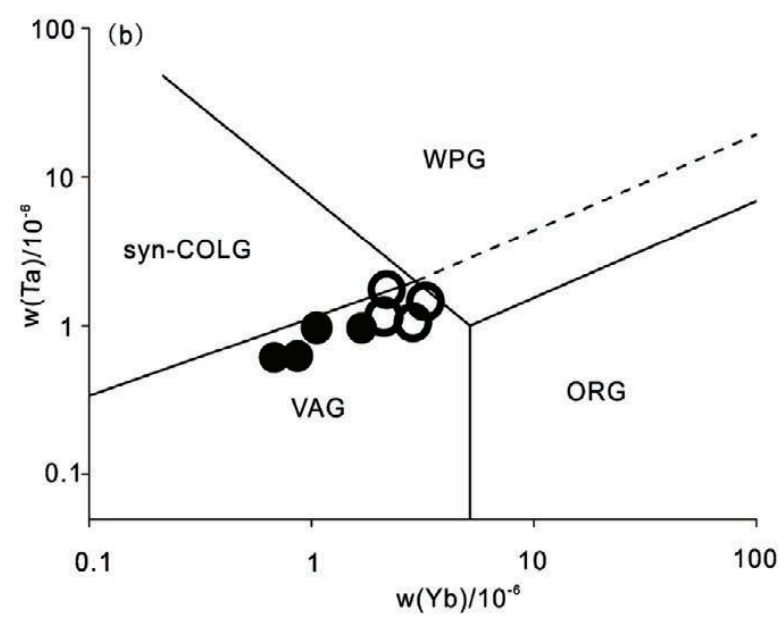

Baocheng

Figure 13. Tectonic discrimination diagrams. (a)-(c) after PEARCE et al. (1984); (d) after HARRIS et al. (1986); (ORG - ocean ridge granites; WPG - within plate granites; VAG - volcanic arc granites; Syn-COLG - syn-collision granites).

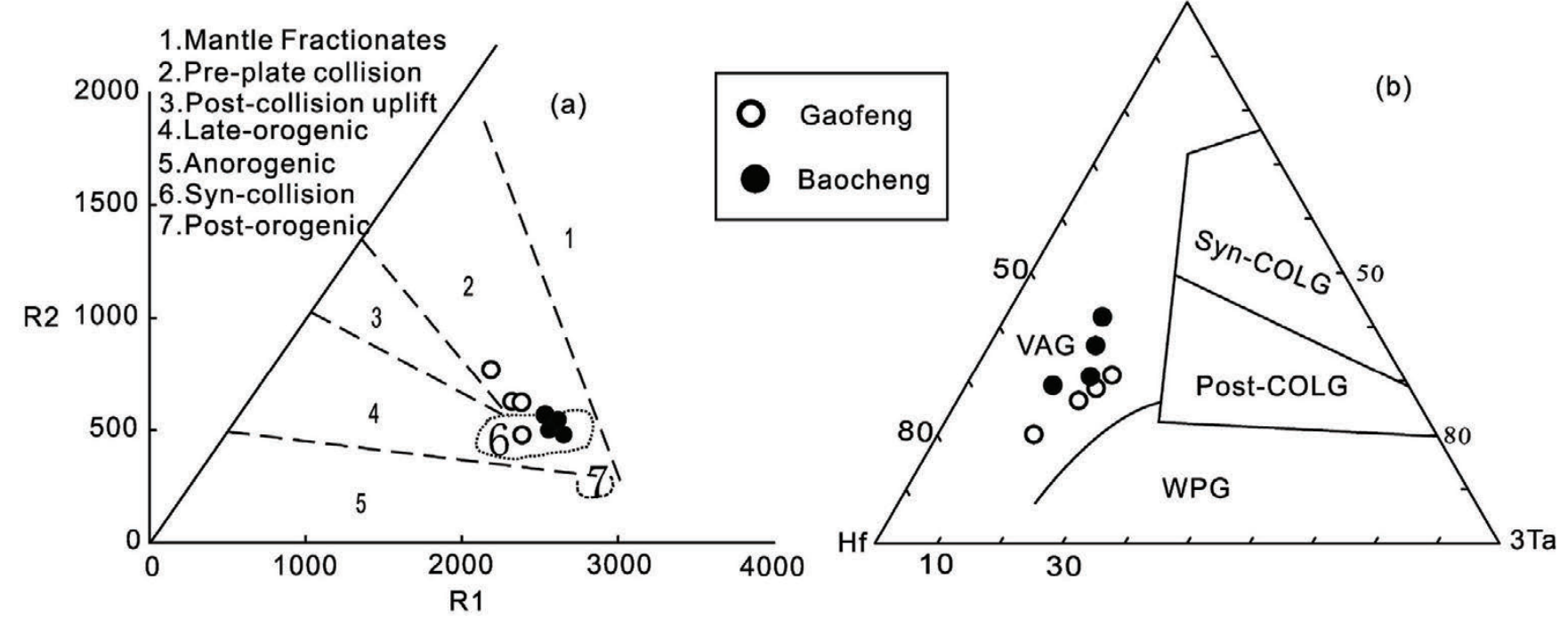

Figure 14. Discriminant diagrams of the tectonic setting (a) $R_{1}$ vs $R_{2}$ (after BATCHELOR \& BOWDEN, 1985); (b) Rb/30-Hf-Ta×3 (HARRIS et al.,1986,) (ORG - ocean ridge granites; WPG - within plate granites; VAG - volcanic arc granites; Syn-COLG - syn-collision granites). 
(a)

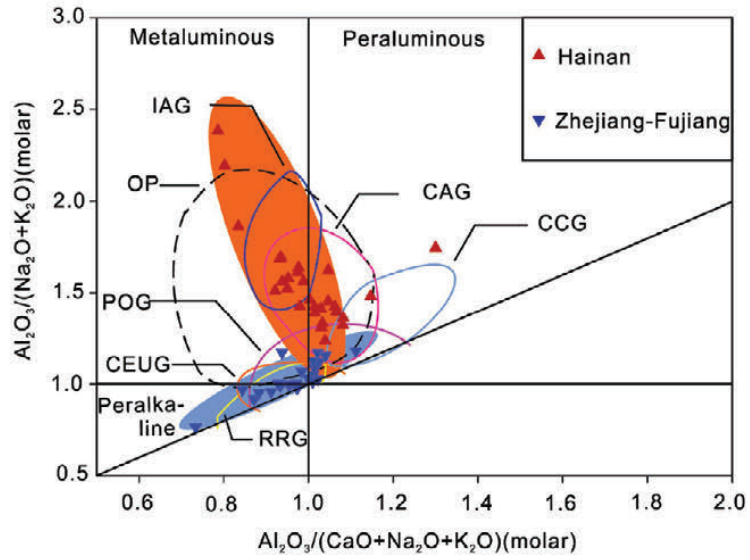

(c)

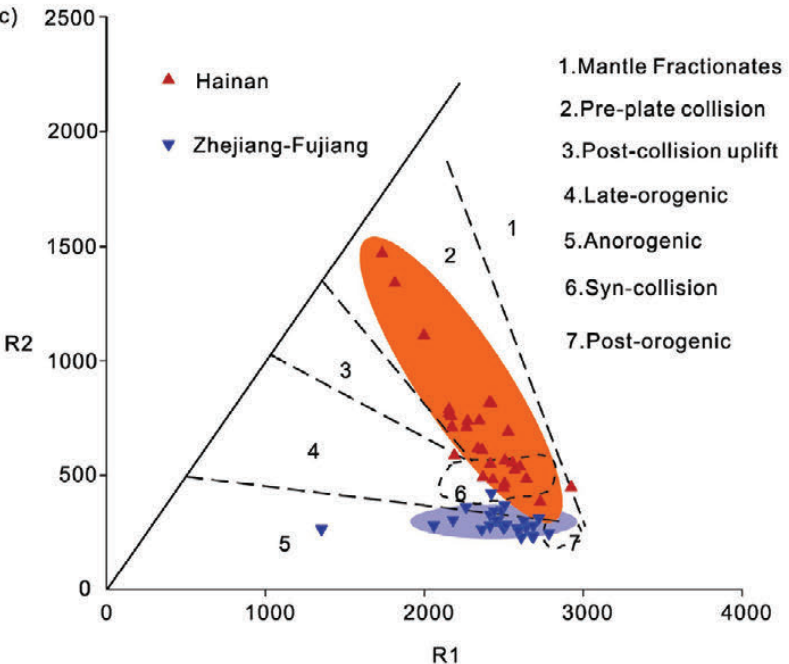

(b)

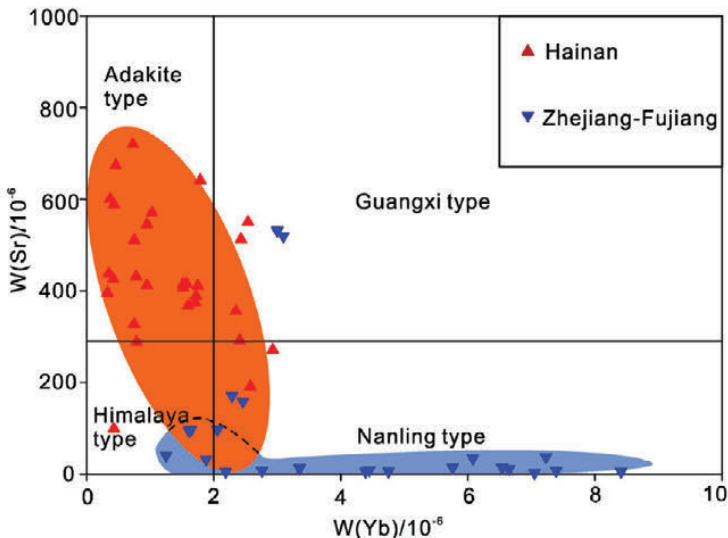

(d)

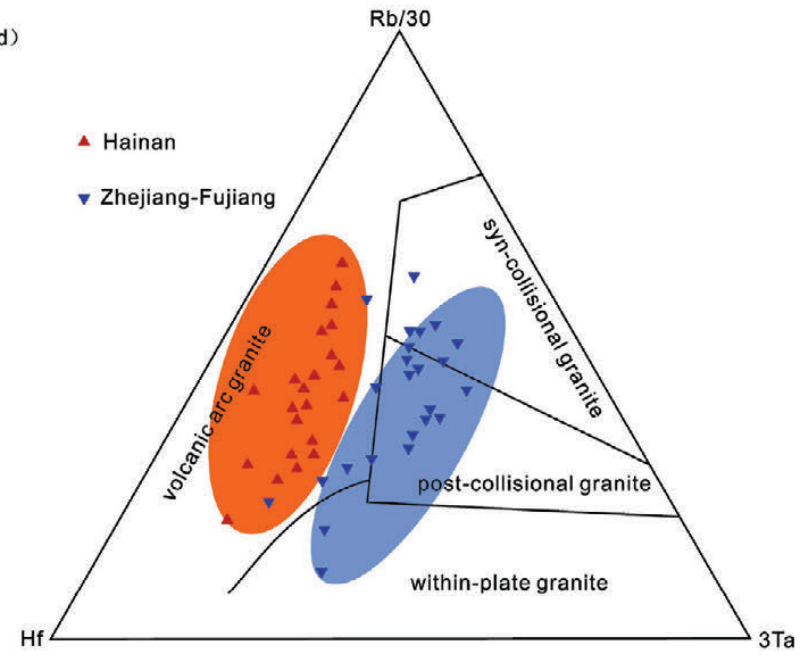

Figure 15. Geochemical diagrams showing a difference in granite between the Hainan and Zhejiang-Fujian granites in the Cretaceous (a) NK-NKC; (b) Sr-Yb, (after ZHANG, Q., 2014); (c) $\mathrm{R}_{1}$ versus $\mathrm{R}_{2}, \mathrm{R}_{1}=4 \mathrm{Si}-11(\mathrm{Na}+\mathrm{K})-2(\mathrm{Fe}+\mathrm{Ti}), \mathrm{R}_{2}=6 \mathrm{Ca}+2 \mathrm{Mg}+\mathrm{Al}$, (after BATCHELOR \& BOWDEN, 1985); (d) Ta-Rb-Hf, (after HARRIS et al., 1986) data from YUN \& XIE (2003); JIA et al. (2010); GE et al. (2003); TANG et al. (2014); CHEN et al. (2013); CHEN et al. (2014); ZHOU \& LI (2000); LI et al. (2013); QIU et al. (2008); THUY et al. (2004); NGUYEN et al. (2004); SHELLNUTT et al. (2013).

(TANG, 2014). In addition, YUN (2004) identified the late stage of the Yanshan granites represented by the Tunchang intrusion in Hainan Island as ACG-type granites, which are typical subduction granites (XIAO, 2002). Their arc characteristics are widely recognized by almost all scholars who study late Mesozoic magmatic rocks in Hainan Island, judging by the published literature referenced herein. JIANG \& LI (2014) considered that Hainan Island was an Andean continental margin arc tectonic environment before 73Ma in the Late Mesozoic.

Moreover, the northward subduction compression tectonics of the ancient Sea provided a necessary high-pressure environment. As a result, the Hainan Province was located in an oceaniccrust subduction tectonic setting in the late Yanshanian period, which would have been an Andean-type continental margin arc environment. This conclusion contradicts the view that magmatism occurred in an extensional setting (GE et al., 2003; YUN et al., 2003; CHEN et al., 2008).

\subsection{IMPLICATIONS FOR REGIONAL GEOLOGY}

The Cretaceous magmatism of Hainan Island and the Fujian and Zhejiang areas was thought to have been related to western Pacific subduction (WANG et al., 2012; JIA et al., 2010; TANG et al., 2014; MAO et al., 2013; LI et al., 2013; WANG et al., 2012).
However, the Cretaceous granites on Hainan Island displayed geochemical signatures different to those of the coeval granites from the Fujian and Zhejiang areas (Fig. 15). Specifically, the granites of Hainan Island have the characteristics of high $\mathrm{Sr}$ (335), low Yb (1.8), low Y (17.1), and high $\mathrm{Sr} / \mathrm{Y}(20)$. Although similar granite characteristics have also been reported from the Fujian and Zhejiang Provinces (CHEN, 2014), it is not possible to explain formation of the granites of Fujian and Zhejiang and those of Hainan Island by the same mechanism. Firstly, granites with high Sr are too rare in Fujian and Zhejiang (ZHANG, 2014; JIA et al., 2010). Secondly, some of the granites in Fujian and Zhejiang are actually Guangxi-type granites (ZHANG, 2014) with high Sr and Yb contents (CHEN, 2013, 2014; ZHAO, 2007; ZHANG, 2005), which differ from the high-Sr, low-Yb granites of Hainan Island. Until now, the miarolitic granite widely distributed along the coast of Zhejiang and Fujian has not been found on Hainan Island. In addition, the majority of the granites in the Late Yanshanian in Hainan Island are I-type granites (WANG et al., 1991).But the granites in Fujian and Zhejiang are composed of A-type and Itypes, and the proportion of I-type granite is far less than that of the Hainan Island I-type granite in Qiongzhou (JIA et al., 2010; ZHANG, 2014; CHEN, 2013; ZHAO et al., 2007). Source area and diagenetic evolution characteristics of the two diagenetic 


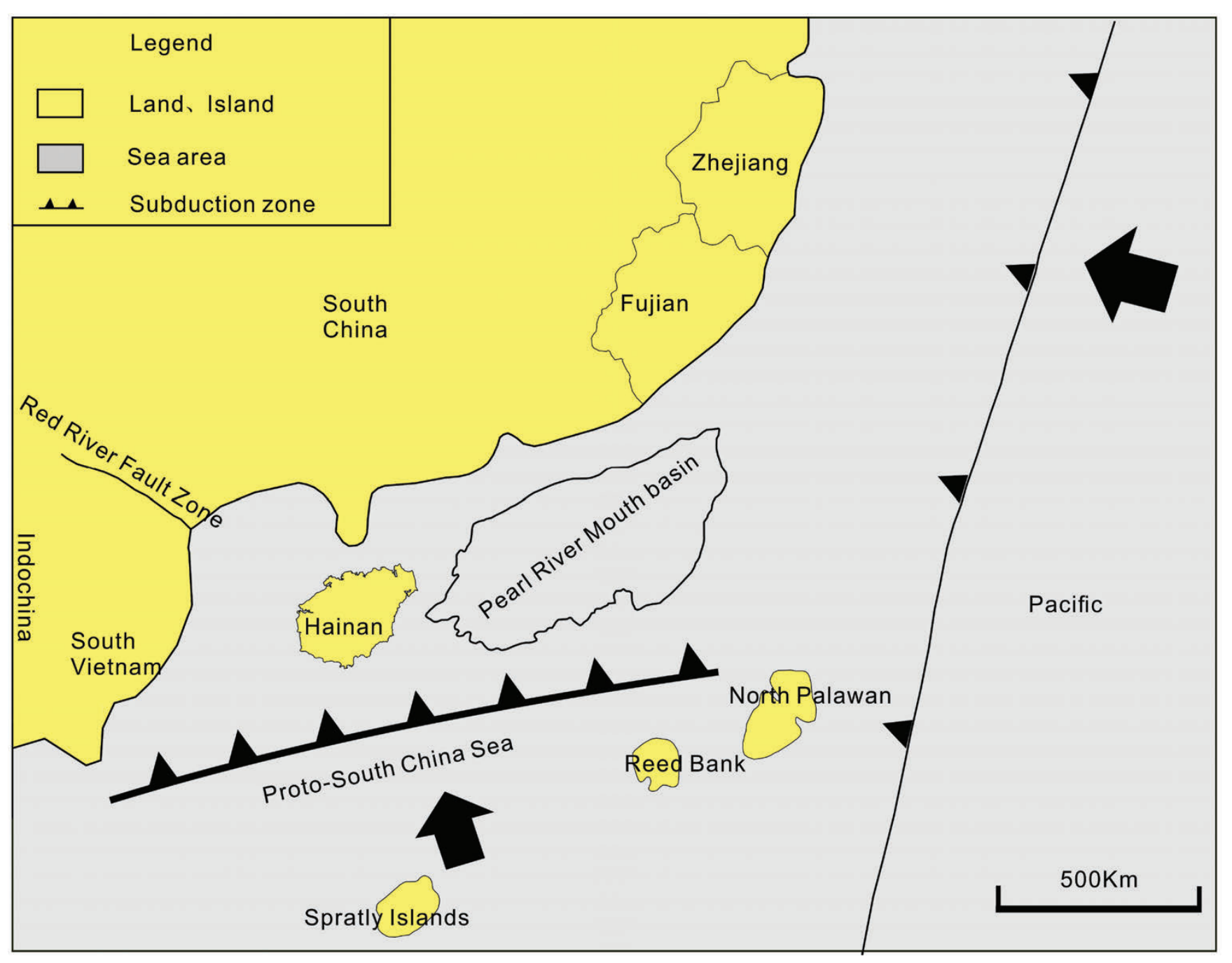

Figure 16. The Cretaceous marginal arc of Hainan Island and its adjacent tectonic setting.

models for I-type granite, the granite in Zhejiang and Fujian provinces is typical for the first one (QIU et al., 2008, 2012; ZHAO et al., 2012), and the granite of Hainan Island belongs to the second species discussed above. Sr-Nd isotopes also show great differences, indicating different magma sources (GE et al., 2003; TANG et al., 2014). This shows that there are fundamental differences in the characteristics of the magma sources and the diagenesis of granites between the two places. The above understanding of the differences between granites from Hainan Island and Fujian-Zhejiang area is in agreement with WANG (1991), who clearly pointed out that the granites in the coastal areas of Fujian and Guangdong are different from the contemporary granites in Hainan Island. Therefore, when discussing the tectonic setting of Yanshanian granite formation in Hainan Island, the important influence of oceanic crust subduction is clearly affirmed, though any claim that the ocean crust belongs to the Western Pacific Ocean is not conclusive here.

If Fujian, Zhejiang, and Hainan Island have been affected by western Pacific subduction during the Cretaceous, then granites with high $\mathrm{Sr} / \mathrm{high} \mathrm{Yb}$ and low $\mathrm{Sr} / \mathrm{high} \mathrm{Yb}$, similar to those in the Zhejiang and Fujian area, should also be present in Hainan Island. The low-Sr, high-Yb granites that widely occur in Fujian and Zhejiang and the high-Sr, low-Yb granites of Hainan Island represent two different tectonic domains. There are significant differences in the Sr-Nd isotopic composition between the regions which indicate that the magmas come from different sources (TANG et al., 2010).

It was previously thought that the Cretaceous granites that formed a record of subduction in Fujian and Zhejiang resulted

Table 4. Comparison of the geological characteristics of the Hainan and Zhejiang-Fujian granites.

\begin{tabular}{|c|c|c|c|c|c|c|c|c|c|c|}
\hline \multirow{2}{*}{ Age (Ma) } & \multicolumn{2}{|c|}{ Type } & \multicolumn{2}{|c|}{ ASD } & \multicolumn{2}{|c|}{ TD } & \multicolumn{2}{|c|}{ DD } & \multicolumn{2}{|c|}{ ZST } \\
\hline & Hainan & ZJ-FJ & Hainan & ZJ-FJ & Hainan & ZJ-FJ & Hainan & ZJ-FJ & Hainan & ZJ-FJ \\
\hline $110-100$ & I-type & I-type & $100 \mathrm{Ma}$ & - & & $\mathrm{PH}$ & & & & \\
\hline $100-90$ & I-type & A-type & - & - & $\mathrm{SH}$ & SL & $E-W$ & NE-SW & $720-770^{\circ} \mathrm{C}$ & $774-819^{\circ} \mathrm{C}$ \\
\hline $90-70$ & - & A-type & - & $80-72 \mathrm{Ma}$ & וזנד & $S L$ & & IVL-SVV & & \\
\hline
\end{tabular}

ASD:The age of associated deposit;TD:Temperature and depth of Rocks generate;DD:Distribution direction of intrusions;SH:Shallow \& High temperatures;PH:Plutonic \& High temperatures;SL:Shallow \& Low temperatures;ZST:Zr saturation temperature;ZJ:Zhejiang; FJ:Fujian.Data from TANG(2010);CHEN(2014);YUN et al.,(2004);ZHOU et al.(1991);LI et al. (2013);GE et al. (2003);ZHAO et al.(2012);KANG et al.(2018). 
from western Pacific subduction. The influence of the western Pacific subduction was confined to the east of Wuyi Mountain, however, Hainan is located to the far west of Wuyi Mountain, therefore the influence of western Pacific subduction could not have reached Hainan Island. ZHU et al. (2002) \& ZHU (2004) believe that the farthest effects of the Pacific plate subduction occur in the Mariana arc, simply because the remaining oceanic crust of late Mesozoic MORB found in the Mariana arc belongs to the Indian Ocean-Tethys type. This also suggests that the subduction plates of mantle components during the diagenesis of granites may not originate from the Palaeo-Pacific plate. As a result, the Hainan Island granites were basically not affected by western Pacific subduction. Instead they were influenced by the northward-subducting ancient Sea in the same location as the present-day South China Sea, prior to the opening of the area during the late Mesozoic (TAYLOR \& HAYES, 1983; ZHOU, 1992; LI, 1987; YAO et al., 1994; XIA et al., 2000; YAN et al., 2005; MIN et al., 2010; LU et al., 2014).

The late Mesozoic granites of Hainan Island have similar geochemical characteristics to granites from the Pearl River Mouth basin and South Vietnam (Fig. 15). Hainan Island and Zhejiang-Fujian area both had similar tectonic settings (i.e., active continental margin) in the Late Mesozoic. However, there have been differences in the chemical composition of granite, the nature of the source area, magmatic processes involved, and the time series of tectonic evolution. The continental margin arc represented by Hainan Island should be a convergent boundary. It extends westward to reach Yazhuang, Suihe and other places in southern Vietnam, and eastward to the Pearl River Mouth Basin, Fig. 16). According to data from previous studies, the northern shelf of the South China Sea, Hainan Island, and Suihe-Yazhuang, after restoring their geo-historical position, were where the Pearl River Mouth Basin is located. This is backed up by their very similar Cretaceous granite and volcanic rock assemblages, and can be connected to the East-West Andean continental margin arc (MO \& SHI, 1987; NGUYEN et al., 2004; THUY et al., 2004; LIANG, 2013; FANG, 2016).

According to TAPPONIER's model (1986), the Indo-China block has slid 650-1200 km southeastward along the Red River Fault since the late Eocene (YANG et al., 1998; LELOUP et al., 1995; WATKINSON et al., 2011; SCHARER et al., 1994). If modeling this backwards in time, South Vietnam should be along a line stretching westward from Hainan Island and the Pearl River Mouth basin. The above three sites constitute a latitudinal zone likely representing the active margin of the ancient sea differing from the Pacific system.

This ancient sea existed before the expansion of the presentday South China Sea and was roughly equivalent to it, which was close to Hainan Island. Fang (2016) named it as the "Tethys South China Sea” after subducting northward and closing the ancient sea area in the late Mesozoic. Whether the Tethys domain really exists in the study area or not, much more detailed and special investigation is required. According to XIA \& HUANG (2000); YAN \& ZHOU (2001); ZHU et al. (2004); LIU et al. (2004); YAN (2005), there should be traces of Tethys in the northern waters of the South China Sea. Although the issue of Tethys is not the main point discussed here, we call the northward subduction of oceanic crust (Hainan island facing) in the Late Mesozoic as the "Tethyan South China Sea” for convenience of description. Based on the present findings, the Palaeo-Sea area facing Hainan Island in the late Mesozoic subduction to the north and the palaeo-Pacific area subducted to the West belong to different tectonic settings. The disappeared Palaeo-Sea area is what we refer to here as the “Tethyan South China Sea”.

Furthermore, the late Yanshanian Tunchang intrusion of Hainan Island was composed of ACG-type granitoid (YUN \& XIE, 2003). Typically, ACG-type granites are granitoids formed in a subduction-zone setting (XIAO et al., 2002). There were different rock types, varying ages, and other contrasting elements between the Hainan and Zhejiang-Fujian locations (Table 4). Hainan Island was more readily affected by subduction of the ancient Sea than by subduction of the western Pacific (Fig. 16).

In summary, the "Tethys South China Sea” facing Hainan Island subducted northward, and the subducted slabs entered the garnet peridotite phase and melted at the base of and intruded into the lower part of Hainan Island to form the primary crust. Another part of the melt was intruded into higher positions along deep and large faults to form basic dykes. With the subduction, the mixed crust formed by the primary crust and the ancient basement crust were partially melted and further intruded into the granitic rocks. With the further intensification of subduction and compression, the crust and therefore the granite was also uplifted and exposed to the surface and denuded at the same time. With the subduction of the ancient Sea, the denuded granite particles were transported and deposited in the sedimentary strata. The occurrence of zircon is reported in the Late Cretaceous strata of Hainan Island and southeast Qiong basin during the early and late Cretaceous.

\section{CONCLUSIONS}

1) High-precision U-Pb zircon dating results indicate that the Gaofeng and Baocheng granites in Hainan island crystallized at 107Ma and $\sim 105 \mathrm{Ma}$.

2) The Gaofeng and Baocheng plutons are high-K calc-alkaline I-type granites, resembling magmatic rocks formed in a continental arc setting.

3) The granites of Hainan Island displayed geochemical signatures differing from those of coeval granites in the Fujian and Zhejiang areas. Both represented different subduction tectonic domains. The Fujian and Zhejiang areas were affected by western Pacific subduction, Hainan Island was more readily affected by subduction of the Tethyan South China Sea.

\section{ACKNOWLEDGEMENT}

Financial support for this research was provided by the National Natural Science Foundation of China (no. 41572207, no. 41276047, no. 41030853)

\section{REFERENCES}

BARR, S.M. \& MACDONALD, A.S. (1981): Geochemistry and geochronology of late Cenozoic basalts of southeast Asia.- Bull. Geol. Soc. Am. (part II), 92/8, 1069-1142. doi: 10.1130/GSAB-P2-92-1069

BATCHELOR, R.A. \& BODWEN, P. (1985): Petrogenetic interpretation of granitoid rock series using multicationic parameters.- Chemical Geol., 48/1, 43-55. doi: 10.1016/0009-2541(85)90034-8

BEARD, J.S. \& LOFGREN, G.E. (1991): Dehydration melting and water-saturated melting of basaltic and andesitic greenstones and amphibolites at 1-3 and 6-9 kbar.Journal of Petrology, 32/2, 365-402.

BELOUSOVA, E.A., GRIFFIN, W., O’REILLY, S.Y. \& FISHER, N.I. (2002): Igneous zircon: trace element composition as an indicator of source rock type.- Contr. Mineral. Petrol., 143/5, 602-622. doi: 10.1007/s00410-002-0364-7

BEN-AVRAHAM, Z. \& UYEDA, S. (1973): The evolution of the China basin and the Mesozoic paleogeography of Borneo.- Earth. Planet. Sci. Lett., 18/2, 365-376. doi: 10.1016/0012-821X(73)90077-0

CASTILLO, P.R., JANNEY, P.E. \& SOLIDUM, R.U. (1999): Petrology and geochemistry of Camiguin island, southern Philippines: Insights to the source of adakites 
and other lavas in a complex arc setting.- Contrib. Mineral. Petrol., 134/1, 33-51. doi: 10.1007/s004100050467

CHAPPELL, B.W. \& WHITE, A.J.R. (1992): I- and S-Type Granites in the Lachlan Fold Belt. Transactions of the Royal Society of Edinburgh.- Earth Sciences, 83/1-2, $1-26$.

CHEN, J.Y., YANG, J.H., ZHANG, J.H. \& SUN, J.F. (2014): Geochemical transition shown by Cretaceous granitoids in southeastern China: Implications for continental crustal reworking and growth.- Lithos, 196-197, 115-130. doi: 10.1016/j.lithos.2014.03.003

CHEN, J.Y., YANG, J.H., ZHANG, J.H., SUN, J.F. \& WILDE, S.A. (2013): Petrogenesis of the Cretaceous Zhangzhou batholith in southeastern China: Zircon U-Pb Age and Sr-Nd-Hf-O isotopic evidence--Academic Annual Meeting of Institute of Geology and Geophysics, Chinese Academy of Sciences, (13th).

CHEN, M.L. (2014): Petrogenesis of the Qian Jia Composite pluton in Hainan Island and its relationship to Mo polymetallic Mineralization.- China. $\mathrm{PhD}$ thesis, China University of Geosciences, $132 \mathrm{p}$.

CHEN, M.L., LI, S.X., ZENG, Y.L. \& ZHOU, J.B. (2008): Petrochemical characteristics and metallogenic analysis of the Cretaceous Qianjia rock bodies in Hainan Island.Mineral Resources and Geology, 22/1, 36-42 (in Chinese with English abstract).

CHEN, W.F., CHEN, P.R., XU, X.S. \& ZHANG, M. (2005): The geochemical characteristics of basalts in south China and its restriction on Pacific plate subduction. Science in China-Ser. D., Earth Sciences, 48/12, 2104-2117.

DEFANT, M.J. \& DRUMMOND, M.S. (1990): Derivation of some modern arc magmas by melting of young subducted lithosphere.- Nature, 347/6294, 662-665. doi: 10.1038/347662a0

FANG, N.Q. (2016): A new model on the Mesozoic "South China Sea” (SCS): Reconstructing the Hainan marginal arc and recognizing the Tethyan SCS.- Earth Science Frontiers, 23/6, 107-119.

GE, X.Y., LI, X.H. \& ZHOU, H.W. (2003): Geochronologic, geochemistry and Sr-Nd isotopes of the Late Cretaceous mafic dyke swarmsin southern Hainan Island.Geochimica, 32/1, 11-20 (in Chinese with English abstract).

GUO, L.Z. (1984): Granitoids in southeastern China: their time-space distribution, tectonic framework and evolution.- Science Technology Publishers, Jiangsu, 38-48.

HAN, Q. (2016): The basic characteristics of Mesozoic-Cenozoic rhyolites in the northern margin of the South China Sea.- Master thesis, School of Ocean Sciences, China University of Geosciences (Beijing), 69 p. (in Chinese with English abstract).

HARRIS, H.B.W., PEARCE, J.A. \& TINDLE, A.G. (1986): Geochemical characteristics of collision zone magmatism.-Collision tectonics, 19/5, 67-81. doi: 10.1144/GSL. SP.1986.019.01.04

HOU, Z.Q., GAO, Y.F., MENG, X.L., QU, X.M. \& HUANG, W. (2004): Genesis of adakitic porphyry and tectonic controls on the Gangdese Miocene porphyry copper belt in the Tibetan orogen.-Acta Petrologica Sinica, 20/2, 239-248.

HUNG, V.N. (1999): Tin potential of high-aluminium granites (Datanky and Ankroetplutons) from the Dalat zone (in Vietnamese).- MSc Thesis, National University of Ho Chi Minh Hutchison CS Geological evolution of Southeast Asia. Clarendon, Oxford.

IRVINE, T.N. \& BARAGAR, W.R.A. (1971): A guide to the chemical classification of the common volcanic rocks.- Canadian Journal of Earth Sciences, 8, 523-548. doi: 10.1139/e71-055

JIA, Y. \& DI, Z. (2001): Advancement on the Meso-Tethys along the Northern margin of the South China Sea.- Marine Geology \& Quaternary Geology, 21/4, 49-54.

JIA, X.H., WANG, Q., TANG, G.J. \& JIANG, Z.Q. (2008): Geochemical characteristics and genesis of intrusive rocks related to Mo-mineral in Tunchang area, Hainan.Bull. Mineral. Petrol. Geochem. 27 (suppl.), 307-309 (in Chinese).

JIA, X.H., WANG, Q. \& ZHAO, W.Q. (2010): Zircon U-Pb geochronology, geochemistry and petrogenesis of the Late Early Cretaceous adakitic intrusive rocks in the Tunchang area, Hainan Province.- Geochimica, 39/6, 497-519 (in Chinese with English abstract).

JOHANNES, W. \& HOLTZ, F. (1996): Petrogensis and Experimental Petrology of Granitic Rocks.- Springer Berlin Heidelberg, 335 p.

KANG, C. et al. (2018): Petrogenesis of Tiangongshan Indosinian Granites in Longyan Area, Southwest Fujian.- Earth Science, 43/12, 4621-4637.

KAY, R.W. (1978): Alertian magnesian andesite: Melts from subducted Pacific Ocean crust.- Volcano. Geotherm. Res., 4/1-2, 117-132.

KHOSHNOODI, K., BEHZADI, M., GANNADI-MARAGHEH, M. \& YAZDI, M. (2017): Alkali Metasomatism and Th-REE Mineralization in the Choghart deposit, Bafq district, Central Iran.- Geologia Croatica, 70/1, 53-69. doi: 10.4154/ gc.2017.03

LELOUP, P.H. (1995): The Ailao Shan-Red River shear zone (Yunnan, China), Tertiary transform boundary of Indochina.- Tectonophysics, 251/1-4, 3-10.

LI, T.G. (1987): Determination and study of density and magnetism of rock of the coast and the islands of the northern South China Sea.- Marine Geology \& Quaternary Geology, 7/3, 57-69 (in Chinese with English abstract).
LI, L.L., ZHOU, H.W., CHEN, Z.H., WANG, J.R., CHEN, Z.H. \& CHEN, W. (2013): Petrogenesis of the Late Mesozoic granitic rocks in southeast coastal areas of Fujian Province and its geological significance.- Geological Bulletin of China, 32/7, 1047-1062 (in Chinese with English abstract).

LI, X.H., ZHOU, H.W., DING, S.J., LI, J.Y., ZHANG, R.J., ZHANG, Y.M. \& GE, W.C. (2000): Hainan island mid-ocean ridge type metamorphic rock: The ancient Tethys oceanic crust fragment? - Chinese science bulletin, 45/1, 84-88 (in Chinese).

LIEGEOIS, J.P., NAVEZ, J., HERTOGEN, J. \& BLACK, R. (1998): Contrasting origin of post-collisional high-K calc-alkaline and shoshonitic versus alkaline and peralkaline granitoids. The use of sliding normalization.- Lithos, 45/1-4, 1-28. doi: 10.1016/S0024-4937(98)00023-1

LING, L.H., PIN, Y. \& YOU, Z.B. (2004): Pre-Cenozoic basements of the South China Sea and eastern Tethyan realm.- Marine Geology \& Quaternary Geology, 24/1, 15-28.

LU, B.L., WANG, P.J., LIANG, J.S., SUN, X.M. \& WANG, W.Y. (2014): Structural Properties of Paleo-south China Sea and their relationship with the Tethys and the Paleo-Pacific tectonic domain.- Journal of Jilin University; Earth Science Edition, 44/5, 1441-1450 (in Chinese with English abstract).

LUDWIG, K.R. (2003): ISOPLOT 3.00: A Geochronological Toolkit for Microsoft Excel.- Berkeley Geochronology Center Special Publication 4, Berkeley.

MA, C.Q., MING, H.L. \& YANG, KG. (2004): An Ordovician magmatic arc at the northern foot of Dabie Mountains: Evidence from geochronology and geochemistry of intrusive rocks.-Acta Petrologica Sinica, 20/3, 393-402.

MACPHERSON, C.G., DREHER, S.T. \& THIRLWALL, M.F. (2006): Adakites without slab melting: High pressure differentiation of island arc magma, Mindanao, the Philippines.- Earth Planet Sci. Lett., 243/3-4, 581-593. doi: 10.1016/j.eps1.2005.12.034

MAHONEY, J.J., FREI, R., TEJADA, M.L.G., MO, X.X., LEAT, P.T. \& NAGLER, T.P. (1998): Tracing the Indian Ocean mantle domain through time: isotopic results from old West Indian, East Tethyan, and South Pacific seafloor.- Journal of Petrology, 39/7, 1285-1306. doi: 10.1093/petroj/39.7.1285

MANIAR, P.D. \& PICCOLI, P.M. (1989): Tectonic discrimination of granitoids.- Geological Society of America Bulletin, 101/5, 635-643. doi: 10.1130/0016-7606(19 89)101\%3C0635:TDOG\%3E2.3.CO;2

MAO, J.R., YE, H.M. \& LI, Z.L. (2013): Magmatism and Mineralization record of extrusion-extensional tectonics of late Mesozoic in Qin Hang suture-zone.- Acta Mineralogica Sinica, (s2), 30-31 (in Chinese with English abstract).

MARTIN, H., SMITHIES, R.H., RAPP, R. \& CHAMPION, D.C. (2005): An over view of adakite, tonalite-trondhjemite-granodiorite (TTG), and sanukitoid: relationships and some implications for crustal evolution.- Lithos, 79/1-2, 1-24.

METCALFE, I. (1988): Origin and assembly of Southeast Asian continental terranes.In: Audley-Charles MG, Hallam A (eds.): Gondwana and Tethys, vol. 37. Geol. Soc. Spec. Publ., London, 101-118.

METCALFE, I. (1996): Pre-Cretaceous evolution of SE Asian terranes.- Geol. Soc. Spec. Publ. London, 106/1, 97-122. doi: 10.1144/GSL.SP.1996.106.01.09

MIDDLEMOST, E. (1994): Naming materials in the magma/igneous rock system.- Earth Science Reviews, 37/3-4, 215-224. doi: 10.1016/0012-8252(94)90029-9

MIN, H., REN, J.Y., GAO, J.Y. \& ZUO, Y.S. (2010): Location of the Ancient Subduction Zone in the Northern South China Sea and its Constrains on the Spreading of the South China Sea Basin.- Geotectonica et Metallogenia, 34/4, 599-605 (in Chinese with English abstract).

MO, Y. \& SHI, Y. (1987): Paleomagnetic study and tectonic evolution of Hainan terrane and its vicinal continental coast the late Mesozoic to Cenozoic.- Journal of Nanjing University (Natural Sciences), 23/3, 521-532.

MUNGALL, J.E. (2002): Roasting the mantle: slab melting and the genesis of major Au and Au-rich Cu deposits.- Geology, 30/10, 915-918. doi: 10.1130/0091-7613(20 02)030\%3C0915:RTMSMA\%3E2.0.CO;2

NGUYEN, T.T.B., SATIR, M., SIEBEL, W. \& CHEN, F. (2004): Granitoids in the Dalat zone, southern Vietnam: age constraints on magmatism and regional geological implications.- International Journal of Earth Sciences, 93/3, 329-340. doi: 10.1007/s00531-004-0387-6

PE-PIPER, G. \& PIPER, J.W. (1994): Miocene magnesian andesites and dacites, Evia, Greece: adakites associated with subducting slab detachment and extension.- Lithos, 31/3-4, 125-140. doi: 10.1016/0024-4937(94)90004-3

PEARCE, J.A., HARRIS, N.B.W. \& TINDLE, A.G. (1984): Trace element discrimination diagram for the tectonic interpretation of granitic rocks.- Journal of Petrology, 25/4, 956-983. doi: 10.1093/petrology/25.4.956

PECCERILLO, A. \& TAYLOR, S.R. (1976): Geochemistry of Eocene calc-alkaline volcanic rocks from the Kastamonu area, northern Turkey.- Contributions to Mineralogy and Petrology, 58/1, 63-81. doi: 10.1007/BF00384745

PETFORD, N. \& ATHERTON, M. (1996): Na-rich partial melts from newly underplated basaltic crust: the Cordillera Blanca Batholith, Peru.- Journal of Petrology, 37/6, 1491-1521. doi: 10.1093/petrology/37.6.1491

OKAY, A.I., SATIR, M., MALUSKI, H., SIYKO, M., MONIE, P., METZGER, R. \& AKYZ, S. (1996): Paleo- and Neo-Tethyan events in northwestern Turkey: geo- 
logical and geochronological constraints.- In: YIN A. \& HARRISON T.M. (eds.): The tectonic evolution of Asia, 111/3, 543-8.

PITCHER, W.S. (1983): Granite type and tectonic environment.- In: HSUK (ed.): Mountain Building Processes. Academic Press. London, 19-40.

QIANG, M.L. (2016): The basic characteristics of Cretaceous andesites in the northern margin of South China Sea and compare with the andesites of southeast China.Thesis master, School of Ocean Sciences, China University of Geosciences (Beijing), 53 p. (in Chinese with English abstract).

QIU, J., ZHEN, L.I. \& LIU, L. (2012): Petrogenesis of the Zhangpu Composite Granite Pluton in Fujian Province: Constraints from Zircon U-Pb Ages, Elemental Geochemistry and Nd-Hf Isotopes.- Acta Geologica Sinica, 86/4, 561-576.

QIU, J.S., XIAO, E., HU, J., XU, X.S., JIANG, S.Y. \& LI, Z. (2008): Petrogenesis of highly fractionated I-type granites in the coastal area of northeastern Fujian Province: Constraints from zircon U-Pb geochronology, geochemistry and Nd-Hf isotopes.-Acta Petrologica Sinica, 24/11, 2468-2484.

SCHARER, U., ZHANG, L.S. \& TAPPONNIER, P. (1994): Duration of strike slip movements in large shear zones: The Red River belt, China.-Earth and Planet. Sci. Lett., 126/4, 379-397. doi: 10.1016/0012-821X(94)90119-8

SEN, C. \& DUNN, T. (1994): Dehydration melting of a basaltic composition amphibolite at 15 and $20 \mathrm{GPa}$ implications for the origin of adakites.- Contributions to Mineralogy and Petrology, 117/4, 394-409.

SHELLNUTT, J.G., LAN, C.Y., LONG, T.V., USUKI, T., YANG, H.J. \& MERTZMAN, S.A. (2013): Formation of Cretaceous cordilleran and post-orogenic granites and their microgranular enclaves from the Dalat zone, southern Vietnam: Tectonic implications for the evolution of Southeast Asia.- Lithos, 12/182-183, 229-241. doi: 10.1016/j.lithos.2013.09.016

SISSON, T.W., RATAJESKI, K., HANKINS, W.B. \& GLAZNER, A.F. (2005): Voluminous granitic magmas from common basaltic sources.- Contrib. Mineral Petrol., 148/6, 635-661. doi: 10.1007/s00410-004-0632-9

SKJERLIE, K.P. \& PATIÑO, DOUCE, A.E. (2002): The fluid-absent partial melting of a zoisite-bearing quartz eclogite from 1-0 to 3-2 GPa: implications for melting in thickened continental crust and for subduction-zone processes.- Journal of Petrology, 43/2, 291-314.

SORENSEN, S.S. \& GROSSMAN, J.N. (1989): Enrichment of trace elements in garnet amphibolites from a paleo-subduction zone: Catalina schist, southern California.Geochimica et Cosmochimica Acta, 53/12, 3155-3177. doi: 10.1016/00167037(89)90096-3

SUN, S.S. \& MCDONOUGH, W.F. (1989): Chemical and isotopic systematic of oceanic basalts: Implications for mantle composition and process.- In: SAUDERS, A.D. and NORRY, M.J. (eds.): Magmatism in the Ocean Basins. Geological Society Special Publication, 42, 313-345. doi: 10.1144/GSL.SP.1989.042.01.19

TANG, L.M. (2010): Magmatic evidence of two tectonic extension events during the Mesozoic in Hainan Island \& geodynamic implications.- PhD thesis, Zhejiang University, 118 p. (in Chinese with English abstract).

TANG, Z.Y. (2014): Approach to the sedimentological and geochemical characteristics of the Cretaceous continental basins in northern margin of the South China Sea. - Thesis, master. School of Ocean Sciences, China University of Geosciences (Beijing), 65 p. (in Chinese with English abstract).

TANG, L.M., CHEN, H.L. \& DONG, C.W. (2014): Zircon U-Pb dating and tectonic significance of late Mesozoic granodiorite and its enclaves from Hainan Island.Chinese Journal of Geology, 49/1, 259-274 (in Chinese with English abstract).

TAPPONIER, P., PELTZER, G. \& LE DAIN, A.Y. (1982): Propagating extrusion tectonics in Asia: New insights from simple experiments with plasticine.- Geology, 10/12, 611-616. doi: 10.1130/0091-7613(1982)10\%3C611:PETIAN\%3E2.0.CO;2

TAYLOR, B. \& HAYES, D.E. (1983): Origin and history of the South China Sea basin. The tectonic and geologic evolution of Southeast Asian seas and islands: Part 2, 23-56. doi: 10.1029/GM027p0023

TIEN, P.C., AN, L.D. \& BACH, L.D. (1991): Geology of Cambodia, Laos and Vietnam (geological map 1:1,000,000) and its explanatory note. Geol. Surv. Vietnam.

THI, P.T. (1985): Metamorphic complexes of the Socialist Republic of Vietnam.- In: LEE SANG MAN (eds.) L90-95 [Explanatory text of the metamorphic map of South and East Asia $(1: 1,000,000)]$. CGMW-UNESCO.

THUY, T.B.N., SATIR, M., SIEBEL, W., VENNENMANN, T. \& LONG, T.V. (2002): Geochemical and isotopic composition constraints on the petrogenesis of granitoids from the Dalat zone, southern Vietnam.-Asian Earth Sci., 23/4, 467-482.

THUY, N.T.B., SATIR, M., SIEBEL, W., VENNEMANN,T. \& LONG, T.V. (2004): Geochemical and isotopic constraints on the petrogenesis of granitoids from the Dalat zone, Southern Vietnam.- Journal of Asian Earth Sciences, 23/4, 467-482. doi: 10.1016/j.jseaes.2003.06.001

WANG, D.Y. (1998): Preliminary study on genetic type and emplacement mechanism of granite in the Yacheng-Gaocheng area, South Hainan Island.- Guangdong Geology, 13/4, 13-17.

WANG, D.Z. \& ZHOU, X.M. (2000): Characteristics and Petrogenesis of Late Mesozoic Granitic Volcanic-Intrusive Complexes in Southeastern China.- Sciencepress, 6/4, 487-498.
WANG, Q., LI, X.H., JIA, X.H., WYMAN, D., TANG, G.J., LI, Z.X., MA, L., YANG, Y.H., JIANG, Z.Q. \& GOU, G.N. (2012): Late Early Cretaceous adakitic granitoids and associated magnesian and potassium-rich mafic enclaves and dykes in the Tunchang-Fengmu area, Hainan Province (South China): Partial melting of lower crust and mantle, and magma hybridization.- Chemical Geology, 328/11, 222-243.

WANG, X.F., MA, D.Q. \& JIANG, D.H. (1991): Geology of Hainan Island: Magmatite.- Beijing: Geology Publishing House, 155-160 (in Chinese).

WANG, Y., ZHANG, Q. \& QIAN, Q. (2000): Adakite: Geochemical characteristics and tectonic significances.- Chinese Journal of Geology, 35/2, 251-256 (in Chinese with English abstract).

WATKINSON, I. et al. (2011): The timing of strike-slip shear along the Ranong and Khlong Marui faults, Thailand.- Journal of Geophysical Research Solid Earth, 116(B9). doi: 10.1029/2011JB008379

WHALEN, J.B., CURRIE, K.L. \& CHAPPELL, B.W. (1987): A-type granites: geochemical characteristics, discrimination and petrogenesis.-Contributions to Mineralogy and Petrology, 95/4, 407-419. doi: 10.1007/BF00402202

WOLF, M.B. \& LONDON, D. (1994): Apatite dissolution into peraluminous haplogranitic melts: An experimental study of solubilities and mechanisms.- Geochimica et Cosmochimica Acta, 58/19, 4127-4145. doi: 10.1016/0016-7037(94)90269-0

XIA, K.Y. \& HUANG, C.L. (2000): The discovery of Meso-Tethys sedimentary basins in the South China Sea and their oil and gas perspective.- Earth Science Frontiers, 7/3, 227-238. (in Chinese with English abstract).

XIAO, Q.H. (2002): The thinking and research methods of granite-- Beijing: Geological publishing house (in Chinese).

XIONG, X.L., ADAM, J. \& GREEN, T.H. (2005): Rutile stability and rutile melt HF-SE partitioning during partial melting of hydrous basalt: implications for TT-G genesis.- Chemical Geology, 218/3-4, 339-359 (in Chinese with English abstract).

XU, D.R., LIANG, X.Q. \& TANG, H.F. (2000): Geochemical characteristics of metamorphic basic volcanics from the Baoban Group, western Hainan and its tectonic implications. Geotecton. Metallogen., 24/4, 303-313 (in Chinese with English abstract).

XU, J.F., WANG, Q. \& YU, X.Y. (2000): Geochemistry of high-Mg andesites and adakitic andesite from the Sanchazi block of the Mian-Lue ophiolitic mélange in the Qinling Mountains, central China: Evidence of partial melting of the subducted Paleo-Tethyan crust.- Geochemical Journal, 34/5, 359-377.

XU, J.F., WU, J.B., WANG, Q., CHEN, J.L. \& CAO, K. (2014): Research advances of A-dakites and adakitic rocks in China.- Bulletin of Mineralogy, Petrology and Geochemistry, 33/1, 6-13 (in Chinese with English abstract).

YAN, J.X. (2005): Tectonic implications of marine Mesozoic deposits from Kalimantan and Malay Peninsula.- Journal of Tropical Oceanography, 24/2, 26-32 (in Chinese with English abstract).

YANG, S.F., YU, Z.Y., GUO, L.Z. \& SHI, Y.S. (1989): Differentiation of Hainan terrane, the research of paleogeomagnetism and the significance of plate tectonics.- Journal of Nanjing University: Natural Sciences Edition, 1/1-2, 38-46 (in Chinese with English abstract).

YANG, Z.Y., JEAN, B., SUN, Z.M. \& ZHAO, Y. (1998): Tertiary Squeeze-out of the Indo-China Block and Lithospheric Evolution of the Qinghai-Tibetan Plateau.Acta Geologica Sinica, 72/2, 112-125.

YAO, B.C., ZENG, W.J., CHEN, Y.Z. \& ZHANG, X.L. (1994): Xisha trough of South China Sea: An ancient suture. - Marine Geology \& Quaternary Geology, 14/1, 1-10 (in Chinese with English abstract).

YUAN, H.L., WU, F.Y., GAO, S., LIU, X.M., XU, P. \& SUN, D.Y. (2003): Zircon U-Pb Geochronology, Rare Earth elements of Cenozoic intrusion in northeast China.Chinese Science Bulletin, 48/14, 1511-1520 (in Chinese).

YUN, P., WU, Y.B. \& XIE, S.Z. (2004): Origin of rock-forming minerals from some late Yanshanian granite bodies in Hainan Island.- Geology and mineral resources of South China, 4, 1-8.

YUN, P. \& XIE, S.Z. (2003): The genesis type of upper Mesozoic Tunchang rock body in Hainan Island and its tectonic significance.- Guangdong Geology, 18/4, 9-14 (in Chinese with English abstract).

ZANDT, G., GILBERT, H., OWENS, T.J., DUCEA, M., SALEEBY, J. \& JONES, C.H. (2004): Active foundering of a continental arc root beneath the southern Sierra Nevada in California.- Nature, 431/7004, 41-46. doi: 10.1038/nature02847

ZHANG, G.S., WEN, H.J. \& QIU, Y.Z. (2004): Geochemistry of the Late Mesozoic mafic dykes in western Fujian Province.- Geochimica, 33/3, 243-253 (in Chinese with English abstract).

ZHANG, Q. (2014): Geodynamic implications of continental granites.-Acta Petrologica et Mineralogica, 33/4, 785-798 (in Chinese with English abstract).

ZHANG, Q., LI, C.D., WANG, Y., WANG, Y.L., JIN, W.J., JIA, X.Q. \& HAN, S. (2005): Mesozoic high-Sr and Low-Yb granitoids and low-Sr and high-Yb granitoids in eastern China: comparison and geological implications.-Acta Petrologica Sinica, 21/6, 1527-1537 (in Chinese with English abstract). 
ZHANG, Q., WANG, Y., QIAN, Q., YANG, J.H., WANG, Y.L., ZHAO, T.P. \& GUO, G.J. (2001): The characteristics and tectonic-metallogenic significances of the adakites in Yanshan period from eastern China.- Acta Petrologica Sinica, 2/2, 36-44 (in Chinese with English abstract).

ZHANG, Y.M., ZHANG, R.J., YAO, H.Z. \& MA, G.G. (1997): The Precambrian crustal tectonic evolution in Hainan Island.- Earth Sci., 22, 395-400 (in Chinese with English abstract).

ZHAO, J.L., QIU, J.S. \& ZHEN, L.I. (2012): Petrogenesis of the Taiwushan granite pluton in Fujian Province: Constraints from zircon U-Pb ages and Hf isotopes.-Acta Petrologica Sinica, 28/12, 3837-3950.

ZHAO, X.L., MAO, J.R., CHEN, R., XU, N.Z., ZENG, Q.T. \& YE, H.M. (2007): Zircon SHRIMP age and geochemical characteristics of the Caixi puton in southwest- ern Fujian Province.-Acta Petrologica et Mineralogica, 26/3, 223-231 (in Chinese with English abstract).

ZHOU, X.R., WU, K.L., YAN, B.Q., CHEN, A.G. \& WU, Z.T. (1991): The Petrology and Tectonic-Magmatic Dynamics Mechanism of Zhangzhou granite.-Geoscience Journal of Graduate School, China University of Geosciences, 5/2, 106-108.

ZHOU, X.M. \& LI, W.X. (2000): Origin of Late Mesozoic igneous rocks in Southeastern China: implications for lithosphere subduction and underplating of mafic magmas.- Tectonophysics, 326/3-4, 269-287. doi: 10.1016/S0040-1951(00)00120-7

ZHOU, Z.Y. (1992): Transition from transform fault to subduction system: a pattern of continental accretion in Southeast China and its adjacent areas.- Shanghai Geology, 1, 5-11 (in Chinese with English abstract). 